\title{
Sosyal Politika Kapsamında Kamu Kuruluşları Tarafından Bir Dezavantajlı Grup Olarak Engellilere Yönelik Verilen Hizmetlerin Etkinliği: Isparta İli Örneği*
}

\author{
The Efficiency of the Services Offered for the Disabled by Public Institutions as a Disadvantaged \\ Group within the Scope of Social Policy: The Case of Isparta
}

\section{Murşit IŞIK}

Doç. Dr., Süleyman Demirel Üniversitesi, IIIBF,

Çalışma Ekonomisi ve Endüstri İlişkileri Bölümü,

mursitisik@sdu.edu.tr

https://orcid.org/0000-0001-9855-6290
Makale Başvuru Tarihi: 28.02.2021

Makale Kabul Tarihi: 10.04.2021

Makale Türü: Araştırma Makalesi

\author{
Kübra DEMIROK \\ Bilim Uzm., Süleyman Demirel Üniversitesi, SBE, \\ Çalışma Ekonomisi ve Endüstri İlişkileri ABD, \\ kubrademirok.mail@gmail.com \\ https://orcid.org/0000-0001-5900-9403
}

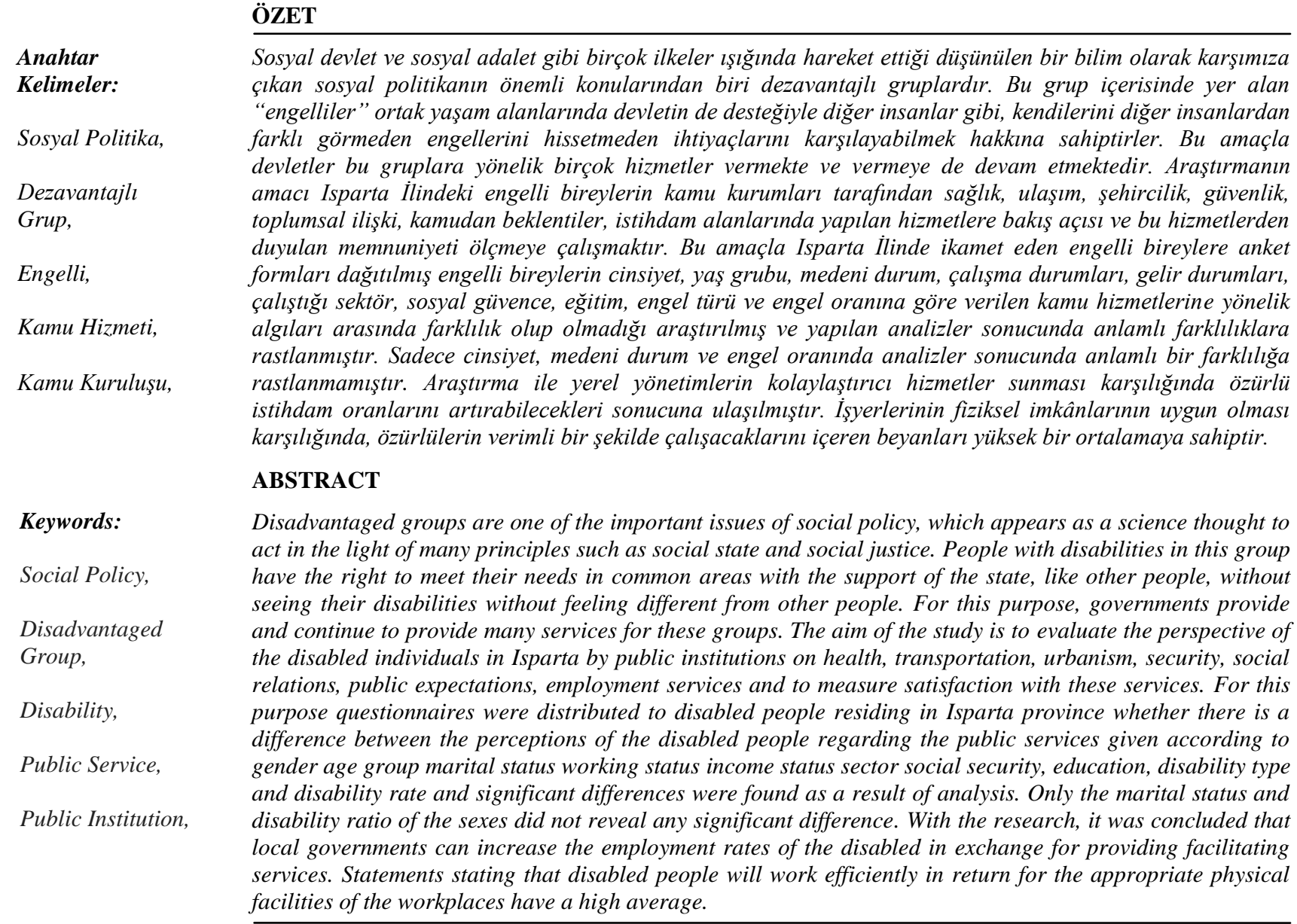

* Bu makale Süleyman Demirel Üniversitesi Sosyal Bilimler Enstitüsünde Doç. Dr. Murşit IŞIK danışmanlığında, Kübra DEMİROK tarafından hazırlanan ve 2019 yılında kabul edilen aynı adlı yüksek lisans tez çalışmasından yararlanılarak hazırlanmıştır. 


\section{Gİiș}

İnsan sosyal, ekonomik ve kültürel bir varlık olup, ihtiyaçlarını karşılamak için tarihin her döneminde farklı şartlarda ve usullerde çalışma şekillerine maruz bırakılmıştır. Bundan dolayı insanı ilgilendiren herşey bilimin konusu içindedir. İnsanlar Sanayi Devrimi döneminde çok katı çalışma kurallarına tabi olmuş ve kol beden gücünün ön planda olduğu bir sürecin içinde kendini bulmuştur. Zamanla teknolojik gelişme ve küreselleşme dediğimiz kavramların ortaya çıkmasıyla insanoğlunun çalışma şekilleri değişiklik göstermiş telefonla çalışma, evde çalışma, part-time çalışma gibi istihdam şekilleri ortaya çıkmıştır. Bu çalışmaların gerçekleştirilme şekli, çalışma (istihdam) ile ilgili politikaların oluşturulması, uygulamaya konması, uygulamada karşılaşılan sorunların çözüme kavuşturulması, çalışma koşullarının iyileştirilmesi, istihdamın arttırılması, etkinlik ve verimliliğin sağlanması gibi birçok konu sosyal bilimler tarafından incelenmiştir. Sosyal bilimler içerisinde yer alan birçok farklı disiplin bu süreç, politika, uygulama ve norm tesisini kendi amaç ve ilkeleri doğrultusunda analiz etmiş̧tir. Sosyal politika da bu amaçla bu konularda araştırma ve incelemelerin yapıldığı bir bilim dalıdır.

Sosyal bir bilim olan sosyal politika kavramına bakıldığında temelde dar anlamlı sosyal politikayı ifade eden işçi, işveren ve devletin olduğu bir döngüyü ifade ediyordu. Daha sonra devlet anlayışında ortaya çıkan değişimler, küreselleşme kavramının ortaya çıkması sonucunda işletme kavramındaki değişim ve küçük ölçekli işletmelerden büyük ölçekli işletmelere geçiş süreçleri fabrikalardaki üretimin sürecinde emeğin (işgücünün) beden ve kol gücünü esas alan anlayış yerine esnek istihdam biçimlerini oluşmuştur. Esnekleşen istihdamla birlikte önceden erkeklerin dâhil olduğu işgücü piyasasına kadınlar, çocuklar, göçmenler, yaşlılar, vb. birçok sosyal grup da dâhil olmuştur. Bu durum “dezavantajlı gruplar” kavramını ortaya çıkarmıştır.

Dezavantajlı gruplar; ekonomik ve sosyal hayata katılımda zorluk çeken bireyler olarak ifade edilebilir (Baydoğan, 2012:3). Dezavantajlı dediğimiz kesim iktisadi ve sosyal hayata katılımda güçlük çeken, sahip olduğu şartlar itibariyle avantajlı olmamayı ifade etmektedir. Dezavantajlı gruplar; kadınlar, çocuklar, gençler, yaşlılar, eski hükümlüler, göçmenler ve engelliler olmak üzere 7 sosyal gruptan oluşmaktadır. Çalışmamızın kapsamı açısından bu sosyal gruplardan tamamı dikkate alınmamıştır. Engelliler, kısıt kabul edilerek araştırma gerçekleştirilmiştir.

Engelli ve engellilik konusu Türkiye'de 1928'de başlayıp, 2014'e kadar devam eden çeşitli hukuk normları ile düzenlenmiştir. Tarihsel süreç içerisinde kavram ve kavramın taşıdığ 1 anlam üzerinde dönüşümler yaşanmıştır. Engelli kavramından önce mevzuatta sakat, özürlü ve malul gibi terimler kullanılmıştır. 2013 yılından bu yana ise ağırlıklı olarak "engelli" terimi tercih edilmektedir. Ancak akademik yazında ve diğer bazı hukuk normlarında halen genel ve tek bir kavram kullanılmamaktadır. Daha doğrusu sakat ve malul gibi terimler halen muhtelif hukuk normlarında terim olarak yer almaya devam etmektedir.

Sanayileşme, kentsel nüfus yoğunluğu ve sosyal kontrol mekanizmasının zayıflaması ve toplumsal değişimin sonucu olarak; insanların yardımlaşma, birlik ve beraberlik gibi duygularının yerini ben merkezli bireysellik anlayışı almaya başlamıştır. Bu durum dezavantajlı yaşam standartlarına sahip olan ve bu sebeple de yalnızlaşma eğilimi yüksek olan engellileri toplumdan yani diğer kişilerden biraz daha uzaklaştırmıştır. Diğger bireylerin engellilere olan destekleyici tavırları ve insancıl yaklaşımlarının yerini zaman zaman küçük görme, önyargılı davranma, acıma, dışlanma ve değersizleştirilme gibi olumsuz davranışların aldığı görülmüştür. Bu durum engelli bireylerin kendisini toplumdan soyutlamalarınına ve toplumsal hayat içindeki aktif rollerinden uzaklaşmalarına neden olmuştur.

İnsanların farklılık oluşturması, engelli bireylere karşı daha anlayışlı davranması ve "her bireyin bir engelli" adayı olduğunu unutmadan hareket etmesi engelliler ile ilgili ortaya çıkan bireysel ve toplumsal olumsuzlukların giderilmesine katkı sağlayacaktır. Engellilik, toplumdan kopuk, özgüvensiz bir yaşamı değil, toplum ile bütünleşmiş ve kendi içerisinde aktif bir rol ile özel bir yaşamı ortaya koymalıdır. Engelin varlığı bazı dezavantajlar ortaya koymuş olsa da inanç, imkân ve çalışma ile bunların birçoğunun aşılabileceği birçok olumlu örnekle ispatlanmış bir gerçektir.

Engelliliğin oluşması sadece istihdam esnasında meydana gelen bir kaza ile sınırlı değildir. Kişilerin doğumu sırasında, doğum öncesinde ve doğum sonrasında da ortaya çıkabilmektedir. Ancak her ne şekilde ortaya çıkarsa çıksın, mevcut olan dezavantajların önemli ölçüde giderilebileceği ve engelliler lehine eğitim ve istihdam aracılığ 1 ile geliştirilebileceği göz ardı edilmemelidir.

Çalışmanın amacı; önemli ve dezavantajlı bir sosyal grup olan engellilerin aldığı kamusal hizmetlerden dolayı duydukları memnuniyet düzeylerinin ölçülmesi ve analiz edilmesidir. Isparta İlinde ikamet eden engelli 
bireylere kamudan almış oldukları sağlı, ulaşım, eğitim ve sosyal aktivite hizmetleri ile toplumsal ilişki, kamudan beklentiler, istihdam ve siyasi haklar ile ilgili memnuniyet düzeyleri ölçülmüştür. Bu kapsamda bağımsız (cinsiyet, yaş, medeni durum, çalışma durumu, gelir durumu, çalışılan sektör, sosyal güvence, eğitim düzeyi, engel türü, engel oranı) değişkenlerin bağımlı değişkenlere etkisini ölçmek amacıyla bir çalışma modeli kurulmuştur. Bu modelde cinsiyet, yaş grubu, medeni durum, çalışma durumu, gelir durumu, çalışılan sektör, engellinin sosyal güvencesi, eğitim düzeyi, engel türü ve engel oranına göre ankette yer alan sağlık, ulaşım, şehircilik, güvenlik, eğitim, sosyal aktivite, toplumsal ilişki, kamudan beklentiler, istihdam ve siyasi haklar ölçeklerine göre anlamlı bir farklılık oluşup oluşmadığı test edilmeye çalışılmıştır.

\section{SOSYAL POLITIKA KAVRAMI VE DEZAVANTAJLI GRUP KAVRAMI}

Sosyal politika kavramı ilk defa 19. yüzyılın ilk yarısında Riehl tarafından kullanmıştır. İki ayrı kelimenin birleşimi olan sosyal politika kavramı 1880 yıllarına kadar akademik olarak bir önem arz etmemiş ve böylelikle de bilimsel çalışmalarda genel anlamda yer almamıştır. Kavramın kullanım amacı, devletin o dönemde var olan burjuva toplumu karşısında yapılan faaliyetleri göstermek ve toplumsal anlamda ilişkinin yansımasını sağlamaktır. Fakat 1873 yılında “Alman Sosyal Siyaset Derneği”"nin kurulması ve sonrasında iktisat biliminin akademik bir disiplin hâline gelmesi ile sosyal politika kavramı kendine özgü bir bilim dalı hâline gelmiştir (Tuna ve Yalçıntaş, 2011:25).

Sosyal politika, Sanayi Devrimiyle birlikte gelen ve güçsüz olan işçi ile işveren arasındaki sınıf farklılı̆̆ının sebep olduğu sorunların çözümünü ifade etmiştir. İşçi - işveren ilişkisinin bozulması nedeniyle toplumun geleceğinin bozulması riskiyle karşı karşıya kalınmıştır. $\mathrm{Bu}$ nedenle devlet sosyal politika sürecine dâhil olmuştur. Zamanla devletin almış olduğu tedbirlerin de alanı genişletilerek sosyal politikanın kapsam ve etkinliği de genişlemiştir (Tokol, 1997:1-2). Sosyal politikanın inceleme alanlarının genişlemesi, dezavantajlı gruplara olan ilgi ve önemin de artmasına katkı sağlamıştır.

Sosyal yaşam ve bazı evrelere katılmada zorluk yaşayan bireyler olarak ifade edilen dezavantajlı gruplar hassas, marjinalize ve korumasız gruplar gibi farklı kavramlar ile de ifade edilmektedir. $\mathrm{Bu}$ ifadelerden en s1k rastlanılanı dezavantajlı ve dışlanan grup kavramlarıdır. Bu ifadeler aynı anlamları karşılamak için geliştirilmiş olsa da kendi içlerinde bazı anlam farklılıklarına da sahiptirler. Dezavantajlı grup kavramı, bir yönüyle diğer kesime göre faaliyette bulunma eksikliği yaşayan veya mali yönüyle avantaj sahibi olmayan kesimleri ifade etmektedir. Bireylerin dışlanmışlıklarından bahsedebilmek için herhangi bir yönüyle avantaj sahibi olmama durumunu oluşturan, bireylerin diğer bireyler ve kurumlar aracılığıyla ortaya çıkan politika ve tutumların ortaya çıkması gerekir; Yani dışlayan bir varlığa ihitiyaç vardır (Baydoğan, 2012:3-4).

\section{KAVRAM, KURAM VE İSTIHHDAM AÇISINDAN ENGELLİLİK}

Türkiye'de tesis edilen hukuk normlarında ve literatürde "engelli" kavramı ile birlikte "özürlü", "sakat" ve "malul" gibi terimlerin kullanımı ile de karşılaşılabilmektedir. 2013 yılı itibariyle kanun metninde ve akademik yazında "engelli" kavramının tercih edilmeye başlandığ 1 görülmektedir. Bununla birlikte anayasada sakat (md.61) ve özürlü (md.10) kavramları da kullanılmaya devam etmektedir (Mecek ve Güney, 2017:381). Akademik yazında sakat, özürlü ve engelli sözcüklerinin aynı anlamda olduğu varsayımı üzerinden birbirinin yerine kullanılmasına sıklıkla şahit olunmasına rağmen bu kavramlar arasında bazı anlam farklılıkları mevcuttur.

Türkiye'de terminolojide farklılık olmasıyla birlikte mevzuatla ilgili hizmet konularına göre farklı ölçütlere dayanarak farklı tanımlamalar getirilmiştir. Sakatları Koruma Milli Koordinasyon Kuruluna göre, bedensel, zihinsel, duygusal ve sosyal özelliklerinde belirli bir oranda fonksiyon kaybına sebep olan organ yokluğu veya bozukluğu sonucu normal yaşamın gereğine uymayacak seviyede özürlenmiş kişi "sakat" ve onun özürlenme durumu "sakatlık" olarak tanımlanmıştır (T.C Başbakanlık Özürlüler İdaresi Başkanlığı, 1999:73-74). 5378 sayılı "Engelliler Hakkında Kanun"a (md.3/c) göre; "fiziksel, zihinsel, ruhsal ve duyusal yetilerinde çeşitti düzeyde kayıplarından dolayı topluma diğer bireyler ile birlikte eşit koşullarda tam ve etkin katılımını kısıtlayan tutum ve çevre koşullarından etkilenen bireye", engelli denilmiştir. Anayasa ile imzalanan uluslararası sözleşme metinlerinde ve yine işbirliği içerisinde bulunulan WHO gibi uluslararası kuruluşlarca yapılmış birbirinden farklı tanımlamalar bulunmaktadır. Belirtilen bu hukuk normlarından hareketle içinde bulunulan zamanın durumun şartlarına ve ihtiyaçlarına göre akademik yazında da çok farklı tanımlamalar geliştirilmiştir. 


\subsection{Engelliliği Açıklamaya Çalışan Modeller}

Özürlülük, gerek nedenleri ve gerekse sonuçları açısından toplumsal bir olgu niteliği taşımaktadır. Tarihsel sürece bakıldığında hem toplumun hem de özürlülerin karşılıklı olarak birbirleri ile girdikleri etkileşimler sonucunda özürlülüğe bakışında değişimler yaşanmıştır. Özürlülüğü kavramaya ve tanımlamaya yönelik yaklaşımlar, sosyal hak kavramını somutlaştıracak biçimde özürlülere yönelik sosyal politikaların oluşmasında doğrudan etkili olmuştur. Tarihsel süreç içerisinde toplumların özürlülüğü ele alış ve değerlendirme biçimleri birbirinden farklılık göstermiştir. Bu farklılık, birbirinin devamı olan dört farklı yaklaşımı ortaya çıkmıştır. Ülkelerin ekonomik, sosyal ve siyasi yapıları da bu yaklaşımların ortaya çıkmasında etkili olmuştur. Bu yaklaşımlar şunlardır (Okur vd., 2010:248);

- Ahlâki Model

- Tibbi Model

- Sosyal Model

- İnsan Hakları Yaklaşımı

Ahlaki model, engellilikten bireyin kendisini sorumlu tutan bir modeldir. Bireylerin kendisinin veya ebeveynlerinin doğru olmayan yani kötü tutumları sebebiyle engelliliğin ortaya çıktığını vurgular. Dini veya geleneksel konular ile engelli bireylerin yaşamlarını düzenler. Engelliliğin ahlâki çöküntüden kaynaklandığını insanın içinde şeytanın veya ahlâksızlığın dışa vurumu olduğunu ileri sürmüştür. Böylece hem engelli birey hem de ailesi büyük bir utançla yaşamlarını sürdürmeye başlamışlardır. Bu engelliliğe ilişkin en eski ve ilk modeldir (Özmete, 2012). Tıbbi Model, engellilik kavramını eksiklik üzerine patolojik bir unsur olarak tanımlanmaktadır. Engelli olmak negatifliğin göstergesidir. Engellilik, bireyi ilgilendiren bir durumdur. Engelliğin sebebiyet verdiği kalıcı sorunlar bireysel tedavi ile iyileştirmeye yönelik müdahalelerle gerçekleşmektedir. Bu modele göre daimi çözüm uzmanlık gerektiren bir iştir (Burcu, 2015:27).

Sosyal modelde, engellilik farklı olmayı gerektirir. Engellilik nötr bir durum olarak kabul edildiği için de toplum ile birey arasındaki bağ korunmalıdır. $\mathrm{Bu}$ modele göre engelliliğin sorunları birey ile toplum etkileşimine göre şekillenmektedir. Çözüm, bireyin kendinde veya toplum - birey ilişkisinde aranmalıdır (Burcu, 2015:27). Son model olan "İnsan Hakları Yaklaşımı" ise, engelliliği temelde insan hakları bağlamında değerlendirmektedir. Engellilerin dışlanabileceği eğitim, ulaşım, istihdam, sağlık, vb. tüm alanlardaki hakları baz alınmış ve bunlara yönelik ulusal ve uluslararası düzeydeki hukuki düzenlemelere vurgu yapılmıştır. Bu bağlamda Birleşmiş Milletler Engelli Bireylerin Hakları Beyannamesi’nde insanın değerli olduğu, ayrımcıllğa maruz kalamayacağı, tüm insan haklarından yararlanmalarının güvence altına alınması, ekonomik, sosyal, kültürel, medeni ve siyasi haklardan yararlanması gerekliliği, yaşam koşullarının iyileştirilmesi gibi temel konular üzerinde durulmuştur (Ünal, 2018:1464).

\subsection{Türkiye'de Engellilere Yönelik Hizmetler}

Engelli bireyler de diğer bireyler ile ulusal ve yerel düzeydeki kamu hizmetlerinden etkin ve verimli bir şekilde yararlanma hakları vardır. Bu sebeple bu haklarını kullanmalarının önünde engel teşkil eden ve fırsat eşitsizliğine yol açan tüm unsurların giderilmesi, bu yönde koruyucu/önleyici tedbirler alınması ve uygulamada ortaya çıkan sorunların çözüme kavuşturulması gerekmektedir. Bu bağlamda gerek merkezi idare olan devlet ve gerekse yerel idareler olan il özel idareleri, belediyeler ve köyler ile bunlara bağlı kurumlar mevzuat ile öngörülen çalışmaları yapmak ve engellilere yönelik kamu hizmetleri üretmek durumundadırlar.

Engelliler ile ilgili en temel kamusal hizmetler mekânsal erişim ve ulaşımları önündeki engellerin kaldırılmasıdır. Kamu binaları, sosyo-kültürel alanlar, ulaşım araçları, sosyal donatılar, vb. alanlara erişimlerinin rahat olabilmesi için engelli rampaları, engelli asansörleri, engellilere uygun merdivenler, kabartmalı yollar, kabartmalı levhalar, sesli bildirim cihazları, vb. uygulamalar hayata geçirilmektedir. Ayrıca bu bağlamda engelliler için e-uygulamalar geliştirilerek mekânsal bağlılıkları azaltılmaktadır. İhtiyaç halinde onlara yardımcı olmaları için destek personeli istihdam edilmektedir.

Engellilerin engellilik oranlarının azaltılmas1/giderilmesi ya da engelleri ile daha konforlu bir hayat sürmeleri için sağlı-rehabilite hizmetleri, eğitsel doküman destekleri, mesleki eğitim imkânları, istihdam olanakları, sosyo-kültürel faaliyetler, sosyal yardımlar, vd. destek hizmetleri de sunulmaktadır. Engelli bireylerin diğer 
engelli bireyler ile kaynaşmaları, dayanışma içinde olmaları ve birbirlerine destekler sunabilmeleri açısından muhtelif organizasyonlar ve uygulamalar hayata geçirilmektedir. Bu kapsamdaki faaliyetlere zaman zaman özel sektör kuruluşları ve STK'lar da destek sağlamaktadırlar.

\subsection{Engelli İstihdamı}

İstihdam, özünde emek arzı ile emek talebi arasındaki dengesizliğin dışa vurumudur. Bu dengesizliğin arkasında çok sayıda ekonomik ve sosyal etken yer alır. Emek arzının arkasında nüfus stoku ve nüfus artış hızı gibi etkenler yer almaktadır. İşgücü talebini ise iktisadi faaliyet hacmi oluşturur. Bir ülkede iktisadi faaliyet hacmi ne kadar geniş olursa ve zamanla yeni faaliyet alanlarının genişleme hızı ne kadar yüksekse işgücü talebinde o oranda yükselme meydana gelecektir. İstihdam konusu içinde engelli isithdamı önemli bir yer tutmaktadır. Türkiye'de kamu ve özel sektörde engelli istihdam etmek kanuni bir zorunluluktur. Bu zorunluluk 4857 say1l İş Kanununda belirtilmiştir (Ölmezoğlu, 2015:23).

Kamu kurumları ulusal, bölgesel ve yerel nitelikte kamu hizmetleri yerine getirmektedir (İzci vd., 2019:302). Kamu ve özel kurumlarda engelli personel istihdamı hukuken bir zorunluluktur. Kamu sektöründe "memur" olarak engelli personel istihdam edilmesi 657 sayılı Devlet Memurları Kanununda (md.53) düzenlenmiştir. Kamu sektörü ve özel sektörde "işçi" olarak istihdam edilecek engelli personelle ilgili temel hükümler de 4857 sayılı İş Kanununda (md.30) düzenlenmiştir (Mecek ve Güney, 2017:384).

Engellilerin istihdam yöntemleri, özürlülerin istihdam edilme mecburiyeti ve bu mecburiyetin yansıması olarak onların nasıl ve ne biçimde istihdam edileceklerine yönelik olan tartışmalarda farklı özürlü istihdam yöntemleri ortaya çıkmıştır. Bunlar şöyle sıralanabilir (Öz ve Orhan, 2012:38-39);

- Kota Yöntemi

- Evde Çalışma Yöntemi

- Kooperatif Çalışma Yöntemi

- Korumalı İşyeri Yöntemi

- Kişisel Çalışma Yöntemi

Avrupa Devletleri 1. Dünya Savaşından sonra kamu ve özel sektörde belirli sayıda özürlünün istihdam edilmesi yönünde faaliyette bulunmuştur. Kota şeklinde özürlü çalıştırma uygulamaları özellikle savaşta sakatlanan harp mâlüllerin istihdamını kolaylaştırmak amacıyla ilk kez Almanya'da 1919 Avusturya 1920 de İtalya 1921 de Polonya ve 1923'te Fransa'da uygulanmıştır (Seyyar, 2006:43). Türkiye'de engelli isitihdamında kota yönteminin uygulanışı, 1967 yılında yürürlüğe giren Deniz İş Kanunu ile meydana gelmiştir (Gönülaçan, 2016:48). Bu yöntemin uygulanış1 ile Türkiye'de kamu ve özel sektörde engellilerin işyerinde çalışabileceği ve işgücüne katkı verebileceği düşüncesi güçlenmiştir (Genç ve Çat, 2013:375).

Evde çalışma yöntemi, işlerin belirli günlerde sakatların ve eski hükümlülerin ikamet edilen yere götürülüp bırakılmasını, iş tamamlandıktan sonrada belirli günlerde ikamet edilen yerden alınıp toplanmasını öngören bir düzenlemedir. Sakatların ve eski hükümlülerin bu yol ile evlerinde çalışarak bir gelir güvencesine sahip olmaları hedeflenmektedir. Evde çalıştırma programlarından başta Fransa Almanya ve ABD olmak üzere birçok ülke faydalanmaktadır (Altan, 2007:206).

Kooperatif çalışma yöntemi, özürlülerin kendi çabaları veya devlet desteği ile kurdukları kooperatif şeklindeki örgütlenmeler ile çeşitli çalışma alanlarından kendilerine çalışma imkânı oluşturmaktadırlar. Böylece işbirliğine dayanan bu yöntem ile özürlüler öncelikle üyelerinin mevcut yetenek ve kapasitelerini değerlendirme, bunları yapacakları işe göre iyileştirme ve bağımsız bir kuruluş olarak alanda faaliyet göstermektedirler (Taşkesen ve Gönüllü Taşkesen, 2015:131).

Korumalı işyeri uygulaması ile öncelikli olarak istihdam piyasasına kazandırılmaları güç olan özürlülerin istihdamı hedeflenmektedir. İkincil hedef ise; bu özürlü gruplarının bir adım ileriye, normal iş piyasalarına geçişinin sağlanmasıdır. Özürlülerin açık çevrede, korumalı binalarda ve işletmelerin üretim üniteleri içerisinde korumalı atölyeler kurularak buralarda istihdam edilmelerini konu edinmektedir (Öz ve Orhan, 2012:41).

Türkiye'de kişisel çalışma yöntemi özürlü istihdamının artmasına yönelik üzerinde durulmayan bir yöntemdir. Bu da özürlü bireylerin basit ve niteliksiz işlere yönelmesine neden olmuştur. Dijital devrimin ortaya çıkardığ 1 sonuçlar düşünüldüğünde bu yöntem bahsedilen gereklilikler yerine getirildiğinde özürlülerin istihdamı 
konusunda önemli roller üstlenebilecek çalışma yöntemi olarak düşünülebilir. Ancak bu yöntemin uygulanmasında devletin üstleneceği rol ve vereceği teşvikler çok önemlidir (Öz ve Orhan, 2012:43).

Bahsedilen yöntemlerin içinde kota yöntemi en yaygın olan yöntemdir. Özellikle son dönemlerde ABD ve İngiltere gibi ülkelerde uygulamadan kaldırıldığ 1 gözlenen bu yöntem hâlâ Türkiye'de ve $A B$ ülkelerinde uygulanan en önemli yöntem olarak görülür (Öz ve Orhan, 2012:38-39).

\section{ENGELLILLERE YÖNELIKK VERÍLEN HIZMETLERIN ETKİNLİĞİ İLE İLGILİ ISPARTA İLI ALAN ARAŞTIRMASI}

Makalenin bu kısmında sırasıyla araştırmanın amacı, kapsamı, önemi, evreni, örneklemi, anket formunun oluşturulması, varsayım ve kısıtları ile bulgulara yer verilmiştir. Araştırmada elde edilen bulgular kendi içerisinde gruplandırılarak açıklanmıştır.

\subsection{Literatür Taraması}

Araştırma ile ile elde edilen bulguların ve ulaşılan sonuçların benzer araştırmalar ile karşılaştırılması, yapılan çalışmanın benzerlik ve farklılıklarını ortaya koyacaktır. Bu bağlamda literatürde mevcut olan benzer çalışmaların kapsamı, evreni, örneklemi, metodolojisi, temel bulguları ve sonuçlarına değinilecektir.

Orhan (2013) tarafından yapılan araştırmada özürlülerin istihdamıyla ilgili hem Türkiye hem de Avrupa Birliği üyesi ülkelerde yapılan uygulamalara ilişkin bir durum analizi amaçlanmıştır. Çalışmada veri toplama aracı olarak anket yöntemi kullanılmıştır. Ankette özürlülerin istihdamına ilişkin sorular kavramsallaştırılıp, içselleştirilmiştir. Anket, çalışan ve çalışmayan özürlüler ile özürlü ailelerine ve işverenlere (4 kesime) uygulanmıştır. Araştırma evreninin İstanbul, Kocaeli, Sakarya ve Ankara'da ikamet eden çalışan özürlülerin, çalışmayan özürlülerin, işverenlerin ve özürlü ailelerinin oluşturduğu çalışmanın içeriği 5 bölümde incelenmiştir. Birinci bölümde refah devleti modelleri; 2. bölümde mevcut özürlü istihdam yönteminin güçlü ve zayıf yönlerinin ortaya çıkarılması incelemesi; 3. bölümde Türkiye ve AB ülkelerinde özürlülerin istihdamına ilişkin durum analizi; 4. bölümde özürlü istihdamında doğrudan rol alan paydaşların özürlü çıkarmaya yönelik alan araştırması; 5. bölümde ise Türkiye'de özürlülerin istihdamına ilişkin somut öneriler ortaya konulmuştur. Araştırma ile yerel yönetimlerin kolaylaştırıcı hizmetler sunması karşılığında özürlü istihdam oranlarını artırabilecekleri sonucuna ulaşılmıştır. İşyerlerinin fiziksel imkânlarının uygun olması karşılığında, özürlülerin verimli bir şekilde çalışacaklarını içeren beyanları yüksek bir ortalamaya sahiptir. Bununla birlikte verilen cevaplar arasında kararsızlıkların çok olduğu görülmüştür. Çalışmada sağlık, ulaşım, şehircilik, güvenlik, eğitim, sosyal aktivite, toplumsal ilişki, kamudan beklentiler, istihdam ve siyasi haklar bağımlı değişkenlerinin demografik unsurlar olan cinsiyet, yaş, medeni durum, gelir durumu, çalışılan sektör, sosyal güvence, eğitim, engel türü ve engel oranının oluşturduğu bağımsız değişkenlerle arasında cinsiyet, medeni durum ve engel oranı ölçekleri dışında anlamlı bir farklılığa rastlanmıştır. Araştırmada engel türü değişkenine göre farklılık analizinde, engel istihdam ölçeğinde ve gelir durumu değişkenine göre farklılık analizinde "sağlık ölçeğinde" kararsızlığa rastlanılmıştır (Orhan, 2013).

Sevgi Engelliler Derneği (2015) tarafından Muş ilinde yapılan çalışmada, engelli bireylerin devlet kurumlarıyla kurmuş oldukları iletişimin kapsamı ve kurum ile engelli bireyler arasında ortaya çıkan sosyolojik dokuyu ortaya çıkarmak amaçlanmıştır. Şehirleşme ve modern devletin zorunlu kıldığı kurumsal gelişmeler sonucunda engelli bireylerin kurumlarla diyalogları nasıl şekillendiği ve bu iletişim ağında engelli bireylerin kurumlarla uyum sağlayıp sağlamadıklarını ve bu kurumlara ilişkin bireylerin memnuniyeti arasında anlamlı bir ilişkinin olup olmadığ ortaya konulmuştur. Çalışmada anket yolu ile elde edilen verilere göre Muşta yaşayan engellilerin başta eğitim ve sağlık olmak üzere birçok temel sorunla karşıllaştıkları ve bu sorunların giderilmesinde yetersiz kalındığı görülmüştür. Bu bağlamda engellilere yönelik olarak çalışmalar yapan kamu kurumları ve sivil toplum kuruluşlarının engelliler ile ilgili faaliyetlerinin yetersiz düzeyde olduğu anlaşılmıştır. Yapılan çalışmada gelir durumu değişkenine göre farklılık analizinde sağl1k ölçeğinde ve sosyal güvence değişkenine göre farkl1lık analizinde eğitim ölçeğinde farklılığa rastlanmıştır (Sevgi Engelliler Derneği, 2015).

Hacıbebekoğlu vd. (2015) tarafindan Nazilli'de yaşayan engelli bireylerin sosyal hayatlarını sürdürürken karşılaştıkları sorunları tespit etmek, toplumsal farkındalığının arttırılmasına katkıda bulunmak, engellilerin kamu kurumlarından beklenti ve isteklerini tespit etmek amacıyla yapılan araştırma sonucunda, ilçede şehir içi toplu taşıma araçlarından memnun olunmadığı görülmüştür. Engelli katılımcılar tarafından, toplu taşıma 
araçlarının fiziki yapısının engelliler için uygun olmadığı, engelliler için gerekli donanıma sahip olunmadığı ve engellilere özel ayrılmış herhangi bir koltuğun bulunmadığı sıklıkla dile getirilmiştir. Ayrıca durak yapılarının engelliler için uygun olmadığı saptanmıştır. Otobüslerde zaman zaman görevli personel ve engelli yolcular arasında sorun yaşandığ 1 belirtilmiş olup, nedeninin ise karşı tarafin psikolojisinin tam olarak anlaşılmamasından kaynaklandığı sonucuna ulaşı1mıştır (Hacıbebekoğlu vd., 2015).

Şahan (2018) tarafından Tekirdağ İli Süleymanpaşa İlçesinde yapılan araştırmada, engellilerin çalışma hayatına katılımında yaşadıkları sorunların kaynakları tespit edilmeye çalışılmıştır. Hazırlanan ölçek 50 engelli birey üzerinde uygulanmıştır. Devletin engellilerin istihdam edilebilmesi için sağladığı olanakların katılımcılar için yeterli olup olmadığı araştırılmıştır. Elde edilen sonuçlara göre katılımcıların, bu hizmetlerden duydukları memnuniyet düzeylerinin "kararsız" oldukları belirlenmiştir. Bunun nedenlerinin başında şehir merkezlerinde devletin engellilere sağladığı kamu hizmetlerinin ilçelere göre daha fazla olması, engellilerin kırsal kesimlerde bu tür hizmetlere ulaşmakta zorluk çekmeleri olduğu tespit edilmiştir. (Şahan, 2018).

\subsection{Araştırmanın Amacı, Kapsamı ve Önemi}

$\mathrm{Bu}$ araştırmanın amacı, engelli bireylerin kamu kuruluşları tarafından sağlanan hizmetlerin etkinliğini ölçmektir. Araştırma, Isparta İlinde ikamet eden ve dezavantajlı bir grup olan engelli bireyleri kapsamaktadır. Engelli bireylerin sorunları, farklı türlerde, sayılarda ve boyutlardadır. Sosyal, özel ve iş yaşamının her aşamasında engelli bireylerin katlanmak zorunda kaldıkları bir sorun ile karşılaşılabilmektedir. Basit bir örnek olarak, evlerin, kamusal alanların, sosyal tesislerin, ulaşım araçlarının, vb. fiziksel alanların büyük bir çoğunluğunda halen engellei rampaları ve asansörleri bulunmamaktadır ya da engelllere uygun ve yeterli olarak oluşturulmamıştır. Bu nedenle de engellilerin en temel ihtiyaçlarını karşılamalarında ya da gündelik yaşamlarını sürdürmelerinde bile engellerle karşılaştıkları görülmektedir. Bu engellerin tespit edilmesi ve mevcut kamusal hizmetlerin yeterlilik düzeyleri ile bu hizmetlerden duyulan memnuniyet düzeylerinin tespit edilmesi, ilgili hizmetlerde maksimum düzeyde etkinlik ve verimliliğin sağlanması açısından çok önemlidir. Bu öneme binaen engelliler ile ilgili kamu politikaları ve uygulamalarına veri kaynağı oluşturabilmek amacıyla Isparta ilinde ikamet eden engellinin sorunları ve engelli bireylerin devlet tarafından sağlanan hizmetlere bakış açıları ve bu hizmetlerden duyulan memnuniyet düzeylerini ölçmek için bu araştırma yapıllmıştır.

\subsection{Araştırmanın Evreni ve Örneklemi}

Araştırmanın evreni 2019 yılında, Isparta İlinde ikamet eden engelli bireylerdir. Yürüme Engelliler Derneği tarafından bu sayının tahmini olarak 11.000 civarında olduğu bildirilmiştir. Buradan hareketle araştırmanın evreni 11.000 olarak belirlenip, araştırmanın örneklemi ${ }_{+} 0.10$ örnekleme hatası ve $\% 90$ güven aralığında 96 kişiye yapılması yeterliyken, çalışmada bu sayının üzerine çıkılarak 120 kişiye anket uygulanmıştır. Yüzyüze görüşülerek yapılan anketlerden 13 tanesinin eksik ve özensiz cevaplandırıldığı tespit edilmiştir. Bu anketler değerlendirme kapsamından çıkartılarak, kalan 107 anket değerlendirmeye alınmıştır.

\subsection{Anket Formunun Oluşturulması}

Anket birincil kaynaklardan cevapların alınması amacıyla oluşturulan sistematik bir bilgi formudur. Araştırmada veri toplama aracı olarak 2015 yılında "Nazilli'de Engellilerin Memnuniyet Analizi" adlı çalışmada kullanılan açık uçlu tarzda sorulan mülakat sorularından oluşturulmuştur. Bu sorular likert ölçeğine çevrilerek anket formu haline getirilmiştir. Katılımcılara demografik unsurları içeren 10 adet soru sorulmuştur. Katılımcılara sorulan soruların tamamı kapalı uçludur. Engelli bireylerin devlet tarafından sağlanan ulaşım, sağlık, istihdam, siyasi haklar ve güvenlik gibi unsurlar kategorize edilerek bireylerin memnuniyeti ölçülmeye çalış1lmıştır. Örnek alınan çalışmanın anketi "evet" ve "hayır" şeklinde olup, 5'li likert ölçeğine göre düzenlenmiştir. 1.Kesinlikle katılmıorum, 2.Katılmıyorum, 3.Kararsızım, 4.Kesinlikle Katılıyorum, 5.Katılıyorum, şeklinde katılımcılardan bu soruları cevaplandırılmaları istenmiştir (Hacıbebekoğlu vd., 2015). 


\subsection{Araştırmanın Varsayımları ve Kısıtlıııkları}

Araştırmanın temel varsayımı; "bağımsız değişkenler (cinsiyet, yaş, medeni durum, çalışma durumu, gelir, çalıştığl sektör, sosyal güvence, eğitim, engel türü ve engel oranı) ile bağımlı değişkenler (sağllk, ulaşım, şehircilik, güvenlik, eğitim, sosyal aktivite, toplumsal ilişki, kamudan beklenti, istihdam, siyasi haklar) arasında farklılık vardır", şeklinde olup bunu belirleyebilmek amacıyla Anova ve T-testi analizleri yapılmıştır. Araştırmanın temel kısıtları şunlardır;

- Bu çalışma sadece Isparta İli sınırları içinde ikamet eden engelli bireyleri kapsamaktadır.

- Yapılan çalışma ${ }_{+} 0.10$ örnekleme hatası ve \%90 güven aralığında 107 kişiyle yüzyüze anket yapılarak gerçekleştirilmiştir.

- Durumlarından dolayı rahatsızlık duyan engelli bireylerin birçoğu da anketi cevaplamak istememiştir.

- Çalışma dezavantajlı grup içindeki engelli bireylerin araştırma modelinde yer alan bağımlı değişkenlerin bağımsız değişkenlere göre farklılaşıp farklılaşmadığı varsayımına dayandırılmıştır.

\subsection{Araştırmanın Bulguları}

Yapılan araştırma sonucunda elde edilen bulgular "betimleyici bulgular" ve "istatistikî bulgular" olarak kendi içinde gruplandırılmıştır. Sırasıyla bu gruplara ve içerisinde bulunan bulgulara değinilecektir.

\subsubsection{Araştırmada Elde Edilen Betimleyici Bulgular}

Araştırmanın bu kısmında katılımcıların demografik özelliklerini yansıtan bulgulara yer verilmiştir. Bu bulgular 10 ayrı tablo üzerinde hazırlanarak analiz edilmiştir.

Tablo 1. Araştırmaya Katılanların Cinsiyet Dağılımı

\begin{tabular}{|c|c|c|}
\hline Cinsiyet & Say1 & Yüzdelik \\
\hline Erkek & 73 & 68,2 \\
\hline Kadın & 34 & 31,8 \\
\hline Toplam & 107 & 100,0 \\
\hline
\end{tabular}

Araştırmanın örneklemini oluş̧uran 107 kişinin \%68'i erkek (73 kişi), \%31'i de (34 kişi) kadındır. Çalışmanın örneklemine göre erkek engelli bireylerin sayısı kadın engelli bireylerden çok daha fazladır.

Tablo 2. Araştırmaya Katılanların Yaş Grubu Dağılımı

\begin{tabular}{|c|c|c|}
\hline Yaş Grubu & Sayı & Yüzdelik \\
\hline $0-9$ & 12 & 11,2 \\
\hline $10-19$ & 14 & 13,1 \\
\hline $20-29$ & 17 & 15,9 \\
\hline $30-39$ & 37 & 34,6 \\
\hline $40-49$ & 17 & 15,9 \\
\hline $50-59$ & 8 & 7,5 \\
\hline $60-69$ & 2 & 1,9 \\
\hline Toplam & 107 & 100,0 \\
\hline
\end{tabular}

Araştırmanın örneklemini oluşturan 107 kişinin \%11,2'si 0-9 yaş aralığında; \%13,1'i 10-19 yaş aralığında; \%15,9'u 20-29 yaş aralığında; \%34,6'sı 30-39 yaş aralığında; \%15,9'u 40-49 yaş aralığında; \% 7,5'i 50-59 yaş aralığında ve \%1,9'u 60-69 yaş aralığında dağılım göstermektedir. Bu çalışmanın genel dağılıma bakıldığında araştırmadaki en geniş katılımlı sosyal grubun \%34,6 (37 kişi) ile 30-39 yaş aralığındaki kişiler olduğu tespit edilmiştir. Katılımcılar arasındaki 50 yaş altı diğer gruplar arasında çok fazla bir yüzdelik fark 
bulunmamaktadır. Ancak 50 yaş üstü engelli katılımcı oranı \%9,4 (10 kişi) tek bir grup olarak düşünülürse diğer gruplara oransal açıdan yaklaşmaktadır.

Tablo 3. Araştırmaya Katılanların Medeni Durumlarının Dağılımı

\begin{tabular}{|c|c|c|}
\hline Medeni Durum & Sayı & Yüzdelik \\
\hline Evli & 46 & 43,0 \\
\hline Bekâr & 61 & 57,0 \\
\hline Toplam & 107 & 100,0 \\
\hline
\end{tabular}

Araştırmanın örneklemini oluşturan 107 kişinin \%43'ünün (46 kişi) evli ve \%57'sinin de (61 kişi) bekâr olduğu tespit edilmiştir. Çalışmanın örneklemine göre bu tablo esas alındığında bekâr engelli bireylerin evli engelli bireylerden daha fazla olduğu görülmüştür.

Tablo 4. Araştırmaya Katılanların Çalışma Durumlarının Dağılımı

\begin{tabular}{|c|c|c|}
\hline Çalışma Durumu & Sayı & Yüzdelik \\
\hline Çalışıyor & 57 & 53,3 \\
\hline İşsiz & 40 & 37,4 \\
\hline Emekli & 10 & 9,3 \\
\hline Toplam & 107 & 100,0 \\
\hline
\end{tabular}

Araştırmanın örneklemini oluşturan 107 kişinin \%53,3'ünün çalıştığı, \%37,4'ünün işsiz olduğu, \%9,3'ünün ise emekli olduğu tespit edilmiştir. Çalışmanın örneklemine göre bu tablo verileri dikkate alındığında araştırmaya katılan engellilerin (57 kişi) yarısından fazlası çalıştığı tespit edilmiştir. Bu verilere göre çalış(a)mayan engelli bireylerin oran $1 \% 37,4$ ile 40 kişidir.

Tablo 5. Araştırmaya Katılanların Gelir Durumlarının Dağılımı

\begin{tabular}{|c|c|c|}
\hline Gelir Durumu (TL) & Say1 & Yüzdelik \\
\hline 1000 ve altı & 1 & 0,009 \\
\hline $1001-3000$ & 32 & 29,9 \\
\hline $3001-5000$ & 33 & 30,8 \\
\hline 5001 ve üzeri & 1 & 0,009 \\
\hline Gelir Yok & 40 & 37,4 \\
\hline Toplam & 107 & 100,0 \\
\hline
\end{tabular}

Araştırmanın örneklemini oluşturan 107 kişinin \%0,009'u 1000 TL ve altı, \%29,9’u 1001-3000 TL arası, \%30,8'i 3001-5000 TL arası, \%0,009'u 5001 TL ve üzerinde gelire sahip olduğu tespit edilmiştir. Katılımcıların $\% 37,4$ 'ünün ise gelirinin olmadığ 1 görülmüştür. Çalışmanın örneklemi esas alındığında Isparta İlindeki engelli katılımcıların "gelir durumlarına" göre dağılımında \%37,4 ile en fazla "geliri olmayan" sosyal grup (40 kişi) öne çıkmaktadır. 1000 TL ve altında düşük gelire sahip sadece 1 kişinin olduğu tespit edilmiştir.

Tablo 6. Araştırmaya Katılanların Çalıştığı Sektörün Dağılımı

\begin{tabular}{|c|c|c|}
\hline Sektör & Sayı & Yüzdelik \\
\hline Kamu & 54 & 50,5 \\
\hline Özel & 3 & 2,8 \\
\hline İşsiz+Emekli & 50 & 46,7 \\
\hline Toplam & 107 & 100,0 \\
\hline
\end{tabular}

Araştırmanın örneklemini oluşturan 107 kişinin \% 50,5'inin kamu sektöründe ve \%2,8'inin de özel sektörde istihdam edildiği tespit edilmiştir. \%46,7'lik bir kesim ise "işsiz" ya da "emekli" olan engelli bireylerden oluşmaktadır. Çalışmanın örneklemi esas alındığında Isparta İlindeki engelli katılımcıların "istihdamdaki sektörel dağılımlarına" göre \%50,5 ile en fazla "kamu sektörü” (54 kişi) grubu öne çıkmaktadır. 
Tablo 7. Araştırmaya Katılanların Sosyal Güvencelerinin Dağılımı

\begin{tabular}{|c|c|c|}
\hline Sosyal Güvence & Sayı & Yüzdelik \\
\hline Evet & 97 & 90,7 \\
\hline Hayır & 10 & 9,3 \\
\hline Toplam & 107 & 100,0 \\
\hline
\end{tabular}

Araştırmanın örneklemini oluşturan 107 kişinin \%90,7'si sosyal güvencesi olan engellilerden, \%9,3'ü ise sosyal güvencesi olmayan engellilerden oluştuğu tespit edilmiştir. Çalışmanın örneklemi esas alındığında Isparta İlindeki engelli katılımcıların "sosyal güvence" dağılımına göre $\% 90,7$ oran ile tamamına yakınının bir sosyal güvenceye sahip olduğu görülmektedir.

Tablo 8. Araştırmaya Katılanların Eğitim Durumlarının Dağılımı

\begin{tabular}{|c|c|c|}
\hline Eğitim & Say1 & Yüzdelik \\
\hline Okuma-yazma bilmeyen & 14 & 13,1 \\
\hline İlköğretim & 20 & 18,7 \\
\hline Ortaöğretim & 14 & 13,1 \\
\hline Lise & 28 & 26,2 \\
\hline Önlisans & 10 & 9,3 \\
\hline Lisans & 20 & 18,7 \\
\hline Yüksek Lisans/Doktora & 1 & 0,009 \\
\hline Toplam & 107 & 100,0 \\
\hline
\end{tabular}

Araştırmanın örneklemini oluşturan 107 kişinin \%13,1'i okuma yazma bilmeyen, \%18,7'si ilköğretim, \%13,1'i ortaöğretim, \%26,2'si lise, \%9,3'ü önlisans, \%18,7'si lisans, \%0,009'u da yüksek lisans ya da doktora seviyesinde eğitim kurumundan mezun olan kişilerden oluştuğu tespit edilmiştir. Çalışmanın örneklemi esas alındığında Isparta İlindeki engelli katılımcıların "eğitim düzeyine" göre \%26,2 ile en fazla "lise" düzeyinde (28 kişi) eğitime sahip oldukları görülmektedir.

Tablo 9. Araştırmaya Katılanların Engel Türüne Göre Dağılımı

\begin{tabular}{|c|c|c|}
\hline Engel Türü & Sayı & Yüzdelik \\
\hline İşitme & 3 & 2,8 \\
\hline Fiziksel & 41 & 38,3 \\
\hline Görme & 30 & 28,0 \\
\hline Süreğen Hastalık & 10 & 9,3 \\
\hline Zihinsel & 14 & 13,1 \\
\hline Ruhsal ve Duygusal & 1 & 0,009 \\
\hline Otizm & 8 & 7,5 \\
\hline Toplam & 107 & 100,0 \\
\hline
\end{tabular}

Araştırmanın örneklemini oluşturan 107 kişinin \%2,8'i işitme, \%38,3'ü fiziksel, \%28'i görme, \%9,3'ü süreğen hastalık, \%13,1'i zihinsel, \%0,009'u ruhsal ve duygusal, \%7,5'i ise otizm türünde engele sahip olduğu tespit edilmiştir. Genel dağılıma bakıldığında katılımcıların en fazla $(\% 38,3)$ fiziksel, en az $(\% 0,009)$ ise ruhsal ve duygusal engel türüne sahip oldukları görülmüştür.

Tablo 10. Araştırmaya Katılanların Engel Oranlarının Dağılımı

\begin{tabular}{|c|c|c|}
\hline Engel Oranı & Say1 & Yüzdelik \\
\hline$\% 81-\% 100$ & 39 & 36,4 \\
\hline$\% 61-\% 80$ & 24 & 22,4 \\
\hline$\% 40-\% 60$ & 40 & 37,4 \\
\hline$\% 39-\% 20$ & 4 & 3,7 \\
\hline Toplam & 107 & 100,0 \\
\hline
\end{tabular}


Araştırmanın örneklemini oluşturan 107 kişinin \%36,4'ünün \%81-\%100 arası engel oranına, \%22,4'ünün \%61$\% 80$ arası engel oranına, \%37,4'ünün \%40-\%60 arası engel oranına, \%3,7'sinin \%39-\%20 aras1 engel oranına sahip oldukları tespit edilmiştir. Çalışmanın örneklemi esas alındığında Isparta İlindeki engelli katılımcıların en fazla $(\% 36,4)$ "\%81-\%100 arast" engel oranina ve en az $(\% 3,7)$ "\%39-\%20 arasl" engel oranına sahip oldukları görülmüştür.

\subsubsection{Araştırmada Elde Edilen İstatistikî Bulgular}

Araştırmanın bu kısmında katılımcıların istatistiki özelliklerini yansıtan bulgulara yer verilmiştir. Bu bulgular 11 ayrı tablo üzerinde hazırlanarak analiz edilmiştir.

Tablo 11. Anket Güvenilirlik Testi

\begin{tabular}{|c|c|}
\hline Boyut/Ölçek & Cronbach's Alfa Katsayısı \\
\hline 51 Madde & 0,829 \\
\hline
\end{tabular}

Araştırmada kullanılan tüm ölçeğin (51 madde) güvenilirlik analizi (Cronbach's Alpha) 0,829 olarak tespit edilmiştir. Buradan hareketle yapılan anketin güvenilirliği $(0.60 \leq \alpha \leq 0.90)$ "oldukça güvenilir" olarak ifade edilebilir. Bu sonuç çalışma ile elde edilen bulguların "oldukça güvenilir" olduğunu ortaya koymaktadır.

Tablo 12. Cinsiyet Değişkenine Göre Farkl11ık Analizi

\begin{tabular}{|c|c|c|c|c|c|}
\hline Boyutlar & Grup & Sayı (N) & Ortalama & St.Sapma & $\mathbf{p}$ \\
\hline \multirow{2}{*}{ Sağlık } & Kadın & 34 & 2,49 & 0,60750 & \multirow{2}{*}{0,230} \\
\hline & Erkek & 73 & 2,40 & 0,76412 & \\
\hline \multirow{2}{*}{ Ulaşım } & Kadın & 34 & 2,58 & 0,90475 & \multirow{2}{*}{0,427} \\
\hline & Erkek & 73 & 2,89 & 0,80490 & \\
\hline \multirow{2}{*}{ Şehircilik } & Kadin & 34 & 2,35 & 0,61973 & \multirow{2}{*}{0,374} \\
\hline & Erkek & 73 & 2,30 & 0,73212 & \\
\hline \multirow{2}{*}{ Güvenlik } & Kadın & 34 & 3,20 & 0,78930 & \multirow{2}{*}{0,336} \\
\hline & Erkek & 73 & 3,40 & 0,90775 & \\
\hline \multirow{2}{*}{ Eğitim } & Kadin & 34 & 2,88 & 0,78622 & \multirow{2}{*}{0,757} \\
\hline & Erkek & 73 & 2,93 & 0,82207 & \\
\hline \multirow{2}{*}{$\begin{array}{c}\text { Sosyal } \\
\text { Aktivite }\end{array}$} & Kadın & 34 & 2,34 & 0,63081 & \multirow{2}{*}{0,095} \\
\hline & Erkek & 73 & 2,44 & 0,86114 & \\
\hline \multirow{2}{*}{$\begin{array}{l}\text { Toplumsal } \\
\text { İlişki }\end{array}$} & Kadin & 34 & 4,30 & 2,03386 & \multirow{2}{*}{0,366} \\
\hline & Erkek & 73 & 4,51 & 1,80657 & \\
\hline \multirow{2}{*}{$\begin{array}{l}\text { Kamudan } \\
\text { Beklenti }\end{array}$} & Kadin & 34 & 2,77 & 0,47960 & \multirow{2}{*}{0,140} \\
\hline & Erkek & 73 & 2,87 & 0,72538 & \\
\hline \multirow{2}{*}{ İstihdam } & Kadın & 34 & 1,87 & 0,72699 & \multirow{2}{*}{0,402} \\
\hline & Erkek & 73 & 2,21 & 0,91722 & \\
\hline \multirow{2}{*}{$\begin{array}{l}\text { Siyasi } \\
\text { Haklar }\end{array}$} & Kadin & 34 & 1,98 & 0,69069 & \multirow{2}{*}{0,430} \\
\hline & Erkek & 73 & 2,16 & 0,82834 & \\
\hline
\end{tabular}

Cinsiyet faktörüne göre anketin alt boyutlarına yapılan farklılık analizi sonucunda tüm boyutlarda "p>0,05" olduğu için anlamlı bir farklılık gözlemlenmemiştir. 
Tablo 13. Yaş Grubu Değişkenine Göre Farklılık Analizi

\begin{tabular}{|c|c|c|c|c|c|}
\hline Boyutlar & Grup & Sayı (N) & Ortalama & St.Sapma & p \\
\hline \multirow{8}{*}{ Sağlık } & $0-9$ & 12 & 2,41 & 0,65759 & \multirow{8}{*}{0,105} \\
\hline & $10-19$ & 14 & 2,81 & 0,77445 & \\
\hline & $20-29$ & 17 & 2,65 & 0,70981 & \\
\hline & $30-39$ & 37 & 2,26 & 0,52716 & \\
\hline & $40-49$ & 17 & 2,24 & 0,79224 & \\
\hline & $50-59$ & 8 & 2,60 & 1,08496 & \\
\hline & $60-69$ & 2 & 1,90 & 0,42426 & \\
\hline & Toplam & 107 & 2,43 & 0,71646 & \\
\hline \multirow{8}{*}{ Ulaşım } & $0-9$ & 12 & 2,58 & 1,06244 & \multirow{8}{*}{0,090} \\
\hline & $10-19$ & 14 & 2,64 & 0,84443 & \\
\hline & $20-29$ & 17 & 2,91 & 0,62115 & \\
\hline & $30-39$ & 37 & 3,08 & 0,75115 & \\
\hline & $40-49$ & 17 & 2,38 & 0,97319 & \\
\hline & $50-59$ & 8 & 2,85 & 0,76862 & \\
\hline & $60-69$ & 2 & 2,25 & 0,82496 & \\
\hline & Toplam & 107 & 2,79 & 0,84605 & \\
\hline \multirow{8}{*}{ Şehircilik } & $0-9$ & 12 & 2,44 & 0,85968 & \multirow{8}{*}{0,577} \\
\hline & $10-19$ & 14 & 2,27 & 0,52950 & \\
\hline & $20-29$ & 17 & 2,31 & 0,68850 & \\
\hline & $30-39$ & 37 & 2,41 & 0,72395 & \\
\hline & $40-49$ & 17 & 2,05 & 0,75907 & \\
\hline & $50-59$ & 8 & 2,20 & 0,55456 & \\
\hline & $60-69$ & 2 & 2,83 & 0,23570 & \\
\hline & Toplam & 107 & 2,31 & 0,69595 & \\
\hline \multirow{8}{*}{ Güvenlik } & $0-9$ & 12 & 3,16 & 0,91287 & \multirow{8}{*}{0,701} \\
\hline & $10-19$ & 14 & 3,32 & 1,23424 & \\
\hline & $20-29$ & 17 & 3,41 & 0,83358 & \\
\hline & $30-39$ & 37 & 3,52 & 0,75412 & \\
\hline & $40-49$ & 17 & 3,11 & 0,91052 & \\
\hline & $50-59$ & 8 & 3,12 & 0,74402 & \\
\hline & $60-69$ & 2 & 3,25 & 0,35355 & \\
\hline & Toplam & 107 & 3,34 & 0,87307 & \\
\hline \multirow{8}{*}{ Eğitim } & $0-9$ & 12 & 3,02 & 0,92600 & \multirow{8}{*}{0,975} \\
\hline & 10-19 & 14 & 3,08 & 0,87490 & \\
\hline & $20-29$ & 17 & 2,86 & 0,73483 & \\
\hline & $30-39$ & 37 & 2,86 & 0,71588 & \\
\hline & $40-49$ & 17 & 2,86 & 0,97675 & \\
\hline & $50-59$ & 8 & 2,87 & 0,84515 & \\
\hline & $60-69$ & 2 & 3,12 & 1,23738 & \\
\hline & Toplam & 107 & 2,91 & 0,80738 & \\
\hline \multirow{7}{*}{$\begin{array}{c}\text { Sosyal } \\
\text { Aktivite }\end{array}$} & $0-9$ & 12 & 2,20 & 0,44452 & \multirow{7}{*}{0,534} \\
\hline & 10-19 & 14 & 2,46 & 0,51548 & \\
\hline & $20-29$ & 17 & 2,62 & 0,72775 & \\
\hline & $30-39$ & 37 & 2,44 & 0,93381 & \\
\hline & $40-49$ & 17 & 2,41 & 0,95401 & \\
\hline & $50-59$ & 8 & 1,95 & 0,50198 & \\
\hline & $60-69$ & 2 & 2,75 & 1,29636 & \\
\hline
\end{tabular}




\begin{tabular}{|c|c|c|c|c|c|}
\hline & Toplam & 107 & 2,41 & 0,79350 & \\
\hline \multirow{8}{*}{$\begin{array}{l}\text { Toplumsal } \\
\text { İlişki }\end{array}$} & $0-9$ & 12 & 4,50 & 2,13201 & \multirow{8}{*}{$0,044^{*}$} \\
\hline & $10-19$ & 14 & 4,92 & 1,63915 & \\
\hline & $20-29$ & 17 & 4,17 & 1,69504 & \\
\hline & $30-39$ & 37 & 4,33 & 1,62042 & \\
\hline & $40-49$ & 17 & 4,26 & 2,03191 & \\
\hline & $50-59$ & 8 & 3,75 & 2,22004 & \\
\hline & $60-69$ & 2 & 2,50 & 1,41421 & \\
\hline & Toplam & 107 & 4,44 & 1,87452 & \\
\hline \multirow{8}{*}{$\begin{array}{c}\text { Kamudan } \\
\text { Beklenti }\end{array}$} & $0-9$ & 12 & 2,87 & 0,53356 & \multirow{8}{*}{0,843} \\
\hline & $10-19$ & 14 & 3,03 & 0,82214 & \\
\hline & $20-29$ & 17 & 2,90 & 0,59827 & \\
\hline & $30-39$ & 37 & 2,72 & 0,64442 & \\
\hline & $40-49$ & 17 & 2,87 & 0,79249 & \\
\hline & $50-59$ & 8 & 2,87 & 0,50718 & \\
\hline & $60-69$ & 2 & 2,59 & 0,32141 & \\
\hline & Toplam & 107 & 2,84 & 0,65698 & \\
\hline \multirow{8}{*}{ İstihdam } & $0-9$ & 12 & 1,30 & 0,54938 & \multirow{8}{*}{$0,000^{*}$} \\
\hline & $10-19$ & 14 & 1,75 & 0,81213 & \\
\hline & $20-29$ & 17 & 2,23 & ,80385 & \\
\hline & $30-39$ & 37 & 2,31 & 0,69195 & \\
\hline & $40-49$ & 17 & 2,58 & 1,11011 & \\
\hline & $50-59$ & 8 & 1,60 & 0,63246 & \\
\hline & $60-69$ & 2 & 2,50 & 0,98995 & \\
\hline & Toplam & 107 & 2,11 & 0,87275 & \\
\hline \multirow{8}{*}{ Siyasi Haklar } & $0-9$ & 12 & 1,58 & 0,48069 & \multirow{8}{*}{0,172} \\
\hline & $10-19$ & 14 & 2,16 & 0,73122 & \\
\hline & $20-29$ & 17 & 2,33 & 0,67280 & \\
\hline & $30-39$ & 37 & 2,11 & 0,83872 & \\
\hline & $40-49$ & 17 & 2,08 & 0,92678 & \\
\hline & $50-59$ & 8 & 2,43 & 0,72887 & \\
\hline & $60-69$ & 2 & 1,62 & 0,88388 & \\
\hline & Toplam & 107 & 2,10 & 0,78841 & \\
\hline
\end{tabular}

$* \mathrm{p}<0,05$

Toplumsal ilişki alt boyutunda "60-69 yaş aralığında" olan engelliler ortalama 2,50 ile "katılmıyorum" cevabı verirken, diğer yaş gruplarında yer alan engelliler ise "katılıyorum ve kesinlikle katılıyorum" cevapları ile farklılaşmaktadır. Buna göre 60-69 yaş aralığında olan engelliler toplumla iletişimde sorunlar yaşamamakta ve kendilerine önyarg1 ile bakıldığını düşünmemektedir. İstihdam alt boyutunda "0-19 yaş aralığı", "10-19 yaş aralığı" ve "50-59 yaş aralığı" içerisinde yer alan katılımcılar sorulara "kesinlikle katılmıorum" cevabı verirken, diğer yaş grubundaki katılımcılar "katılmıyorum" cevabı vermiştir. Burada $p=0,000<0,05$ olarak tespit edilmiştir. Dolayısıyla anlamlı bir farklılık bulunmaktadır. 
Tablo 14. Medeni Durum Değişkenine Göre Farklılık Analizi

\begin{tabular}{|c|c|c|c|c|c|}
\hline Boyutlar & Grup & Sayı (N) & Ortalama & St.Sapma & $\mathbf{p}$ \\
\hline \multirow{2}{*}{ Sağlık } & Evli & 46 & 2.24 & 0,62952 & \multirow{2}{*}{0,191} \\
\hline & Bekâr & 61 & 2,57 & 0,74964 & \\
\hline \multirow{2}{*}{ Ulaşım } & Evli & 46 & 2,84 & 0,92360 & \multirow{2}{*}{0,399} \\
\hline & Bekâr & 61 & 2,76 & 0,78897 & \\
\hline \multirow{2}{*}{ Şehircilik } & Evli & 46 & 2,35 & 0,73502 & \multirow{2}{*}{0,696} \\
\hline & Bekâr & 61 & 2,29 & 0,66989 & \\
\hline \multirow{2}{*}{ Güvenlik } & Evli & 46 & 3,25 & 0,80104 & \multirow{2}{*}{0,201} \\
\hline & Bekâr & 61 & 3,40 & 0,92425 & \\
\hline \multirow{2}{*}{ Eğitim } & Evli & 46 & 2,88 & 0,87359 & \multirow{2}{*}{0,432} \\
\hline & Bekâr & 61 & 2,94 & 0,75982 & \\
\hline \multirow{2}{*}{$\begin{array}{c}\text { Sosyal } \\
\text { Aktivite }\end{array}$} & Evli & 46 & 2,40 & 0,89281 & \multirow{2}{*}{0,151} \\
\hline & Bekâr & 61 & 2,42 & 0,71725 & \\
\hline \multirow{2}{*}{$\begin{array}{l}\text { Toplumsal } \\
\text { İlişki }\end{array}$} & Evli & 46 & 4,19 & 1,83327 & \multirow{2}{*}{0,638} \\
\hline & Bekâr & 61 & 4,63 & 1,89765 & \\
\hline \multirow{2}{*}{$\begin{array}{l}\text { Kamudan } \\
\text { Beklenti }\end{array}$} & Evli & 46 & 2,78 & 0,71617 & \multirow{2}{*}{0,534} \\
\hline & Bekâr & 61 & 2,88 & 0,61077 & \\
\hline \multirow{2}{*}{ İstihdam } & Evli & 46 & 2,23 & 0,84780 & \multirow{2}{*}{0,587} \\
\hline & Bekâr & 61 & 2,01 & 0,88641 & \\
\hline \multirow{2}{*}{ Siyasi Haklar } & Evli & 46 & 2,07 & 0,81592 & \multirow{2}{*}{0,813} \\
\hline & Bekâr & 61 & 2,13 & 0,77268 & \\
\hline
\end{tabular}

Medeni durum faktörüne göre anketin alt boyutlarına yapılan farkl1lık analizi sonucunda tüm boyutlarda "p>0,05" değeri elde edildiği için anlamlı bir farklılık bulunmamaktadır.

Tablo 15. Çalışma Durumu Değişkenine Göre Farklılık Analizi

\begin{tabular}{|c|c|c|c|c|c|}
\hline Boyutlar & Grup & Sayı (N) & Ortalama & St.Sapma & $\mathbf{p}$ \\
\hline \multirow{4}{*}{ Sağlık } & Çalışıyor & 57 & 2,38 & 0,72646 & \multirow{4}{*}{0,139} \\
\hline & İşsiz & 40 & 2,57 & 0,71351 & \\
\hline & Emekli & 10 & 2,10 & 0,57542 & \\
\hline & Toplam & 107 & 2,43 & 0,71646 & \\
\hline \multirow{4}{*}{ Ulaşım } & Çalışıyor & 57 & 2,90 & 0,84864 & \multirow{4}{*}{0,367} \\
\hline & İşsiz & 40 & 2,70 & 0,87257 & \\
\hline & Emekli & 10 & 2,58 & 0,69943 & \\
\hline & Toplam & 107 & 2,79 & 0,84605 & \\
\hline
\end{tabular}




\begin{tabular}{|c|c|c|c|c|c|}
\hline \multirow{4}{*}{ Şehircilik } & Çalışıyor & 57 & 2,38 & 0,69816 & \multirow{4}{*}{0,548} \\
\hline & İşsiz & 40 & 2,24 & 0,65584 & \\
\hline & Emekli & 10 & 2,23 & 0,86138 & \\
\hline & Toplam & 107 & 2,31 & 0,69595 & \\
\hline \multirow{4}{*}{ Güvenlik } & Çalışıyor & 57 & 3,32 & 0,79334 & \multirow{4}{*}{0,341} \\
\hline & İşsiz & 40 & 3,45 & 1,01779 & \\
\hline & Emekli & 10 & 3,00 & 0,62361 & \\
\hline & Toplam & 107 & 3,34 & 0,87307 & \\
\hline \multirow{4}{*}{ Eğitim } & Çalışıyor & 57 & 2,88 & 0,82925 & \multirow{4}{*}{0,724} \\
\hline & İşsiz & 40 & 2,99 & 0,83683 & \\
\hline & Emekli & 10 & 2,80 & 0,56273 & \\
\hline & Toplam & 107 & 2,91 & 0,80738 & \\
\hline \multirow{4}{*}{$\begin{array}{c}\text { Sosyal } \\
\text { Aktivite }\end{array}$} & Çalışıyor & 57 & 2,52 & 0,88573 & \multirow{4}{*}{0,281} \\
\hline & İşsiz & 40 & 2,26 & 0,61068 & \\
\hline & Emekli & 10 & 2,36 & 0,85995 & \\
\hline & Toplam & 107 & 2,41 & 0,79350 & \\
\hline \multirow{4}{*}{$\begin{array}{l}\text { Toplumsal } \\
\text { İlişski }\end{array}$} & Çalışıyor & 57 & 4,16 & 1,57926 & \multirow{4}{*}{$0,046^{*}$} \\
\hline & İşsiz & 40 & 5,00 & 2,08009 & \\
\hline & Emekli & 10 & 3,80 & 2,17562 & \\
\hline & Toplam & 107 & 4,44 & 1,87452 & \\
\hline \multirow{4}{*}{$\begin{array}{c}\text { Kamudan } \\
\text { Beklenti }\end{array}$} & Çalışıyor & 57 & 2,84 & 0,67993 & \multirow{4}{*}{0,410} \\
\hline & İşsiz & 40 & 2,91 & 0,65377 & \\
\hline & Emekli & 10 & 2,60 & 0,51817 & \\
\hline & Toplam & 107 & 2,84 & 0,65698 & \\
\hline \multirow{4}{*}{ İstihdam } & Çalışıyor & 57 & 2,38 & 0,82139 & \multirow{4}{*}{$0,001 *$} \\
\hline & İşsiz & 40 & 1,72 & 0,79574 & \\
\hline & Emekli & 10 & 2,10 & 0,94868 & \\
\hline & Toplam & 107 & 2,11 & 0,87275 & \\
\hline \multirow{4}{*}{$\begin{array}{l}\text { Siyasi } \\
\text { Haklar }\end{array}$} & Çalışıyor & 57 & 2,10 & 0,83979 & \multirow{4}{*}{0,372} \\
\hline & İşsiz & 40 & 2,03 & 0,69149 & \\
\hline & Emekli & 10 & 2,42 & 0,85025 & \\
\hline & Toplam & 107 & 2,10 & 0,78841 & \\
\hline
\end{tabular}

Toplumsal ilişki alt boyutunda çalışan kesim ortalama 4,16 ile emekliler ortalama 3,80 ile "katıliyorum" cevabı verirken, işsiz kesimi oluşturan bireyler "kesinlikle katılıyorum" cevabıyla farklılaşmaktadır. Buna göre çalışan işsiz ve emekli bireyler toplum ile iletişimde sorunlar yaşamakta ve kendilerine önyargı ile bakıldığını düşünmektedirler. Bu katılımcıların cevaplarının aynı kategoride yer almaları, katılımcıların genel dağılımıyla ilgilidir.

İstihdam alt boyutunda işsizler ortalama 1,72 ile "kesinlikle katılmıyorum" cevabı verirken; emekli ve çalışanlar "katılmıyorum" cevabı ile farklılaşmaktadır. Buna göre işsizler, çalışan ve emekli kesim işsiz ve iş aradıklarını, iş ararken de sorunlar yaşadıklarını, il sınırları içerisinde engeline uygun istihdam olanaklarına ulaşabildiklerini, istihdam konusunda yapılan çalışmaları yeterli bulduklarını, çalışma ortamlarının kendileri için uygun olduğunu düşünmemektedirler. Bu katılımcıların, "katılmıorum" ve "kesinlikle katılmıyorum" cevaplarıla aynı kategoride yer almaları, genel dağılımla ilgili bir durumdur. 
Tablo 16. Gelir Durumu Değişkenine Göre Farklılık Analizi

\begin{tabular}{|c|c|c|c|c|c|}
\hline Boyutlar & Grup & Sayı (N) & Ortalama & St.Sapma & p \\
\hline \multirow{4}{*}{ Sağlık } & $1001-3000$ & 33 & 2,49 & 0,74686 & \multirow{4}{*}{0,017 * } \\
\hline & $3001-5000$ & 34 & 2,15 & 0,61705 & \\
\hline & Gelir yok & 40 & 2,61 & 0,71380 & \\
\hline & Toplam & 107 & 2,43 & 0,71646 & \\
\hline \multirow{4}{*}{ Ulaşım } & $1001-3000$ & 33 & 2,77 & 0,73559 & \multirow{4}{*}{0,459} \\
\hline & $3001-5000$ & 34 & 2,94 & 0,91092 & \\
\hline & Gelir yok & 40 & 2,69 & 0,87778 & \\
\hline & Toplam & 107 & 2,79 & 0,84605 & \\
\hline \multirow{4}{*}{ Şehircilik } & $1001-3000$ & 33 & 2,40 & 0,77059 & \multirow{4}{*}{0,673} \\
\hline & $3001-5000$ & 34 & 2,30 & 0,69040 & \\
\hline & Gelir yok & 40 & 2,25 & 0,64489 & \\
\hline & Toplam & 107 & 2,31 & 0,69595 & \\
\hline \multirow{4}{*}{ Güvenlik } & $1001-3000$ & 33 & 2,33 & 0,74652 & \multirow{4}{*}{0,770} \\
\hline & $3001-5000$ & 34 & 3,26 & 0,83698 & \\
\hline & Gelir yok & 40 & 3,41 & 1,00567 & \\
\hline & Toplam & 107 & 3,34 & 0,87307 & \\
\hline \multirow{4}{*}{ Eğitim } & $1001-3000$ & 33 & 2,96 & 0,67534 & \multirow{4}{*}{0,637} \\
\hline & $3001-5000$ & 34 & 2,80 & 0,88988 & \\
\hline & Gelir yok & 40 & 2,96 & 0,84388 & \\
\hline & Toplam & 107 & 2,91 & 0,80738 & \\
\hline \multirow{4}{*}{$\begin{array}{c}\text { Sosyal } \\
\text { Aktivite }\end{array}$} & $1001-3000$ & 33 & 2,45 & 0,73484 & \multirow{4}{*}{0,533} \\
\hline & $3001-5000$ & 34 & 2,50 & 1,04043 & \\
\hline & Gelir yok & 40 & 2,30 & 0,57598 & \\
\hline & Toplam & 107 & 2,41 & 0,79350 & \\
\hline \multirow{4}{*}{$\begin{array}{l}\text { Toplumsal } \\
\text { İlişki }\end{array}$} & $1001-3000$ & 33 & 4,24 & 1,52131 & \multirow{4}{*}{0,151} \\
\hline & $3001-5000$ & 34 & 4,11 & 1,78826 & \\
\hline & Gelir yok & 40 & 4,90 & 2,14596 & \\
\hline & Toplam & 107 & 4,44 & 1,87452 & \\
\hline \multirow{4}{*}{$\begin{array}{c}\text { Kamudan } \\
\text { Beklenti }\end{array}$} & $1001-3000$ & 33 & 2,71 & 0,60621 & \multirow{4}{*}{0,373} \\
\hline & $3001-5000$ & 34 & 2,89 & 0,70636 & \\
\hline & Gelir yok & 40 & 2,91 & 0,65377 & \\
\hline & Toplam & 107 & 2,84 & 0,65698 & \\
\hline \multirow{4}{*}{ İstihdam } & $1001-3000$ & 33 & 2,30 & 0,78122 & \multirow{4}{*}{$0,001^{*}$} \\
\hline & $3001-5000$ & 34 & 2,40 & 0,87315 & \\
\hline & Gelir yok & 40 & 1,70 & 0,80256 & \\
\hline & Toplam & 107 & 2,11 & 0,87275 & \\
\hline \multirow{4}{*}{$\begin{array}{l}\text { Siyasi } \\
\text { Haklar }\end{array}$} & $1001-3000$ & 33 & 2,09 & 0,78017 & \multirow{4}{*}{0,781} \\
\hline & $3001-5000$ & 34 & 2,18 & 0,90518 & \\
\hline & Gelir yok & 40 & 2,05 & 0,69910 & \\
\hline & Toplam & 107 & 2,10 & 0,78841 & \\
\hline
\end{tabular}

$* \mathrm{P}<0,05$

Sağlık alt boyutunda geliri olmayan katılımcılar ortalama 2,61 ile "kararsızım" cevabı verirken, diğer katılımcılar "katılmıyorum" cevabı ile farklılaşmaktadırlar. Buna göre sağlık kurumlarına erişimde zorluk çektiklerine, sağlık hizmetlerinin kalitesinden memnun olduklarına, sağlık kurumlarında hasta-personel ilişkisinde sorun yaşadıklarına, hastanelerin acil servislerinde sorun yaşadıklarına, tedavi, araç-gereç ve ilâçlara erişimde zorluk yaşadıklarına dair net bir görüş belirtmemişlerdir. 
İstihdam alt boyutunda geliri olmayan kesim ortalama 1,70 ile "kesinlikle katılmıyorum" cevabı verirken, diğer katılımcılar "katılmıyorum" cevabı vererek farklılaşmaktadır. Buna göre geliri olmayan ve diğer gelir gruplarına sahip bireyler işsiz olduklarını, iş aradıklarını ve iş ararken sorunlar yaşadıklarını, il sınırları içerisinde engellerine uygun istihdam olanaklarına ulaşabildiklerini, istihdam konusunda yapılan çalışmaları yeterli gördüklerini ve çalışma ortamlarının kendileri için uygun olduklarını düşünmemektedir. Cevapların aynı türde olması, katılımcıların genel dağglımıyla ilgili bir durumdur.

Tablo 17. Çalıştığı Sektör Değişkenine Göre Farklılık Analizi

\begin{tabular}{|c|c|c|c|c|c|}
\hline Boyutlar & Grup & Sayı (N) & Ortalama & St.Sapma & $\mathbf{p}$ \\
\hline \multirow{4}{*}{ Sağlık } & Kamu & 54 & 2,38 & 0,73803 & \multirow{4}{*}{0,797} \\
\hline & Özel & 3 & 2,46 & 0,57735 & \\
\hline & İşsiz+Emekli & 50 & 2,48 & 0,70912 & \\
\hline & Toplam & 107 & 2,43 & 0,71646 & \\
\hline \multirow{4}{*}{ Ulaşım } & Kamu & 54 & 2,91 & 0,86979 & \multirow{4}{*}{0,371} \\
\hline & Özel & 3 & 2,72 & 0,25459 & \\
\hline & İşsiz+Emekli & 50 & 2,68 & 0,83560 & \\
\hline & Toplam & 107 & 2,79 & 0,84605 & \\
\hline \multirow{4}{*}{ Şehircilik } & Kamu & 54 & 2,37 & 0,67868 & \multirow{4}{*}{0,501} \\
\hline & Özel & 3 & 2,55 & 1,18243 & \\
\hline & İşsiz+Emekli & 50 & 2,24 & 0,69184 & \\
\hline & Toplam & 107 & 2,31 & 0,69595 & \\
\hline \multirow{4}{*}{ Güvenlik } & Kamu & 54 & 3,29 & 0,79217 & \multirow{4}{*}{0,576} \\
\hline & Özel & 3 & 3,83 & 0,76376 & \\
\hline & İşsiz+Emekli & 50 & 3,36 & 0,96384 & \\
\hline & Toplam & 107 & 3,34 & 0,87307 & \\
\hline \multirow{4}{*}{ Eğitim } & Kamu & 54 & 2,87 & 0,83659 & \multirow{4}{*}{0,828} \\
\hline & Özel & 3 & 3,08 & 0,80364 & \\
\hline & İşsiz+Emekli & 50 & 2,95 & 0,78845 & \\
\hline & Toplam & 107 & 2,91 & 0,80738 & \\
\hline \multirow{4}{*}{$\begin{array}{c}\text { Sosyal } \\
\text { Aktivite }\end{array}$} & Kamu & 54 & 2,50 & 0,90362 & \multirow{4}{*}{0,215} \\
\hline & Özel & 3 & 2,88 & 0,34694 & \\
\hline & İşsiz+Emekli & 50 & 2,28 & 0,65906 & \\
\hline & Toplam & 107 & 2,41 & 0,79350 & \\
\hline \multirow{4}{*}{$\begin{array}{l}\text { Toplumsal } \\
\text { İlişki }\end{array}$} & Kamu & 54 & 4,12 & 1,59653 & \multirow{4}{*}{0,207} \\
\hline & Özel & 3 & 4,83 & 1,25831 & \\
\hline & İşsiz+Emekli & 50 & 4,77 & 2,13381 & \\
\hline & Toplam & 107 & 4,44 & 1,87452 & \\
\hline \multirow{4}{*}{$\begin{array}{c}\text { Kamudan } \\
\text { Beklenti }\end{array}$} & Kamu & 54 & 2,83 & 0,69168 & \multirow{4}{*}{0,963} \\
\hline & Özel & 3 & 2,93 & 0,50069 & \\
\hline & İşsiz+Emekli & 50 & 2,84 & 0,63666 & \\
\hline & Toplam & 107 & 2,84 & 0,65968 & \\
\hline \multirow{4}{*}{ İstihdam } & Kamu & 54 & 2,37 & 0,84198 & \multirow{4}{*}{$0,002 *$} \\
\hline & Özel & 3 & 2,46 & 0,30551 & \\
\hline & İşsiz+Emekli & 50 & 1,80 & 0,83201 & \\
\hline & Toplam & 107 & 2,11 & 0,87275 & \\
\hline \multirow{4}{*}{ Siyasi Haklar } & Kamu & 54 & 2,08 & 0,85230 & \multirow{4}{*}{0,676} \\
\hline & Özel & 3 & 2,50 & 0,50000 & \\
\hline & İşsiz+Emekli & 50 & 2,11 & 0,73394 & \\
\hline & Toplam & 107 & 2,10 & 0,78841 & \\
\hline
\end{tabular}

$* \mathrm{P}<0,05$ 
İstihdam alt boyutunda işsiz+emekli grubu ortalama 1,80 ile "kesinlikle katılmıyorum" cevabı verirken, diğer katılımcılar "katılmıyorum" cevabıyla farklılaşmaktadır. Buna göre kamu sektörü, özel sektör ve işsiz+emekli grubu işsiz olduklarını, iş aradıklarını ve iş ararken sorunlar yaşadıklarını, il sınırları içerisinde engeline uygun istihdam olanaklarına ulaşabildiklerini, istihdam konusunda yapılan çalışmaları yeterli bulduklarını ve çalışma ortamının kendileri için uygun olduğunu düşünmemektedirler. Cevapların aynı türde olması, katılımcıların genel dağılımıyla ilgili bir durumdur.

Tablo 18. Sosyal Güvence Değişkenine Göre Farklılık Analizi

\begin{tabular}{|c|c|c|c|c|c|}
\hline Boyutlar & Grup & Sayı (N) & Ortalama & St.Sapma & $\mathbf{p}$ \\
\hline \multirow{2}{*}{ Sağlık } & Sosyal Güvencesi olan & 97 & 2,41 & 0,72092 & \multirow{2}{*}{0,957} \\
\hline & Sosyal Güvencesi olmayan & 10 & 2,58 & 0,68928 & \\
\hline \multirow{2}{*}{ Ulaşım } & Sosyal Güvencesi olan & 97 & 2,78 & 0,84168 & \multirow{2}{*}{0,745} \\
\hline & Sosyal Güvencesi olmayan & 10 & 2,95 & 0,91978 & \\
\hline \multirow{2}{*}{ Şehircilik } & Sosyal Güvencesi olan & 97 & 2,33 & 0,70030 & \multirow{2}{*}{0,891} \\
\hline & Sosyal Güvencesi olmayan & 10 & 2,13 & 0,65640 & \\
\hline \multirow{2}{*}{ Güvenlik } & Sosyal Güvencesi olan & 97 & 3,35 & 0,84522 & \multirow{2}{*}{0,182} \\
\hline & Sosyal Güvencesi olmayan & 10 & 3,25 & 1,16070 & \\
\hline \multirow{2}{*}{ Eğitim } & Sosyal Güvencesi olan & 97 & 2,92 & 0,76932 & \multirow{2}{*}{$0,007 *$} \\
\hline & Sosyal Güvencesi olmayan & 10 & 2,90 & 1,16786 & \\
\hline \multirow{2}{*}{$\begin{array}{c}\text { Sosyal } \\
\text { Aktivite }\end{array}$} & Sosyal Güvencesi olan & 97 & 2,44 & 0,81189 & \multirow{2}{*}{0,153} \\
\hline & Sosyal Güvencesi olmayan & 10 & 2,15 & 0,54688 & \\
\hline \multirow{2}{*}{$\begin{array}{l}\text { Toplumsal } \\
\text { İlişki }\end{array}$} & Sosyal Güvencesi olan & 97 & 4,34 & 1,78734 & \multirow{2}{*}{0,085} \\
\hline & Sosyal Güvencesi olmayan & 10 & 5,00 & 2,46588 & \\
\hline \multirow{2}{*}{$\begin{array}{c}\text { Kamudan } \\
\text { Beklenti }\end{array}$} & Sosyal Güvencesi olan & 97 & 2,83 & 0,64274 & \multirow{2}{*}{0,162} \\
\hline & Sosyal Güvencesi olmayan & 10 & 2,96 & 0,81221 & \\
\hline \multirow{2}{*}{ İstihdam } & Sosyal Güvencesi olan & 97 & 2,12 & 0,87295 & \multirow{2}{*}{0,923} \\
\hline & Sosyal Güvencesi olmayan & 10 & 1,98 & 0,90652 & \\
\hline \multirow{2}{*}{$\begin{array}{l}\text { Siyasi } \\
\text { Haklar }\end{array}$} & Sosyal Güvencesi olan & 97 & 2,09 & 0,80571 & \multirow{2}{*}{0,689} \\
\hline & Sosyal Güvencesi olmayan & 10 & 2,20 & 0,62138 & \\
\hline
\end{tabular}

$* \mathrm{P}<0,05$

Eğitim alt boyutunda kurumlarda asansörün olduğu, engelli bireylerin yaşıtları gibi bütün eğitimleri aldığı, engellilerin durumuna uygun mesleki eğitim kurslarının yeterince açıldığı ve engellilerin rehabilitasyonu için yeterince eğitim merkezi olduğuna dair sorulara katılımcıların cevapları " $p=0,007<0,05$ " olmasından dolayı farkl1l1k tespit edilmiştir.

Tablo 19. Eğitim Değişkenine Göre Farklılık Analizi

\begin{tabular}{|c|c|c|c|c|c|}
\hline Boyutlar & Grup & Sayı (N) & Ortalama & St.Sapma & $\mathbf{p}$ \\
\hline \multirow{7}{*}{ Sağlık } & Okuma yazma bilmeyen & 14 & 2,77 & 0,68773 & \multirow{7}{*}{0,486} \\
\hline & İlköğretim & 20 & 2,34 & 0,68395 & \\
\hline & Ortaöğretim & 14 & 2,50 & 0,81807 & \\
\hline & Lise & 28 & 2,42 & 0,79692 & \\
\hline & Önlisans & 10 & 2,26 & 0,66700 & \\
\hline & Lisans & 21 & 2,34 & 0,60048 & \\
\hline & Toplam & 107 & 2,43 & 0,71646 & \\
\hline \multirow{7}{*}{ Ulaşım } & Okuma yazma bilmeyen & 14 & 2,88 & 0,98151 & \multirow{7}{*}{0,316} \\
\hline & İlköğretim & 20 & 2,47 & 0,88733 & \\
\hline & Ortaöğretim & 14 & 2,71 & 0,64856 & \\
\hline & Lise & 28 & 2,76 & 0,85025 & \\
\hline & Önlisans & 10 & 2,93 & 0,83961 & \\
\hline & Lisans & 21 & 3,08 & 0,80038 & \\
\hline & Toplam & 107 & 2,79 & 0,84605 & \\
\hline
\end{tabular}




\begin{tabular}{|c|c|c|c|c|c|}
\hline \multirow{7}{*}{ Şehircilik } & Okuma yazma bilmeyen & 14 & 2,25 & 0,79461 & \multirow{7}{*}{0,284} \\
\hline & İlköğretim & 20 & 2,18 & 0,59702 & \\
\hline & Ortaöğretim & 14 & 2,10 & 0,66541 & \\
\hline & Lise & 28 & 2,38 & 0,76585 & \\
\hline & Önlisans & 10 & 2,20 & 0,59732 & \\
\hline & Lisans & 21 & 2,60 & 0,65293 & \\
\hline & Toplam & 107 & 2,31 & 0,69595 & \\
\hline \multirow{7}{*}{ Güvenlik } & Okuma yazma bilmeyen & 14 & 3,42 & 0,75593 & \multirow{7}{*}{0,307} \\
\hline & İlköğretim & 20 & 3,40 & 1,00786 & \\
\hline & Ortaöğretim & 14 & 3,28 & 1,03244 & \\
\hline & Lise & 28 & 3,28 & 0,73822 & \\
\hline & Önlisans & 10 & 2,80 & 1,05935 & \\
\hline & Lisans & 21 & 3,59 & 0,73517 & \\
\hline & Toplam & 107 & 3,34 & 0,87307 & \\
\hline \multirow{7}{*}{ Eğitim } & Okuma yazma bilmeyen & 14 & 2,85 & 0,86998 & \multirow{7}{*}{0,918} \\
\hline & İlköğretim & 20 & 3,03 & 0,92933 & \\
\hline & Ortaöğretim & 14 & 2,98 & 0,62376 & \\
\hline & Lise & 28 & 2,84 & 0,75259 & \\
\hline & Önlisans & 10 & 3,07 & 0,92082 & \\
\hline & Lisans & 21 & 2,82 & 0,83345 & \\
\hline & Toplam & 107 & 2,91 & 0,80738 & \\
\hline \multirow{7}{*}{$\begin{array}{l}\text { Sosyal } \\
\text { Aktivite }\end{array}$} & Okuma yazma bilmeyen & 14 & 2,27 & 0,51725 & \multirow{7}{*}{0,124} \\
\hline & İlköğretim & 20 & 2,30 & 0,73603 & \\
\hline & Ortaöğretim & 14 & 2,01 & 0,64206 & \\
\hline & Lise & 28 & 2,53 & 0,93553 & \\
\hline & Önlisans & 10 & 2,36 & 0,96801 & \\
\hline & Lisans & 21 & 2,73 & 0,71214 & \\
\hline & Toplam & 107 & 2,41 & 0,79350 & \\
\hline \multirow{7}{*}{$\begin{array}{l}\text { Toplumsal } \\
\text { İlişki }\end{array}$} & Okuma yazma bilmeyen & 14 & 5,00 & 2,02593 & \multirow{7}{*}{0,211} \\
\hline & İlköğretim & 20 & 4,90 & 1,88205 & \\
\hline & Ortaöğretim & 14 & 4,71 & 2,37547 & \\
\hline & Lise & 28 & 3,83 & 1,73234 & \\
\hline & Önlisans & 10 & 4,30 & 1,98886 & \\
\hline & Lisans & 21 & 4,21 & 1,35620 & \\
\hline & Toplam & 107 & 4,44 & 1,87452 & \\
\hline \multirow{7}{*}{$\begin{array}{l}\text { Kamudan } \\
\text { Beklenti }\end{array}$} & Okuma yazma bilmeyen & 14 & 2,74 & 0,51571 & \multirow{7}{*}{0,894} \\
\hline & İlköğretim & 20 & 2,84 & 0,65215 & \\
\hline & Ortaöğretim & 14 & 2,81 & 0,76847 & \\
\hline & Lise & 28 & 2,96 & 0,71214 & \\
\hline & Önlisans & 10 & 2,90 & 0,55621 & \\
\hline & Lisans & 21 & 2,75 & 0,68281 & \\
\hline & Toplam & 107 & 2,84 & 0,65698 & \\
\hline \multirow{7}{*}{ İstihdam } & Okuma yazma bilmeyen & 14 & 1,14 & 0,47993 & \multirow{7}{*}{$0,000 *$} \\
\hline & İlköğretim & 20 & 2,02 & 0,96442 & \\
\hline & Ortaöğretim & 14 & 2,35 & 0,71974 & \\
\hline & Lise & 28 & 2,55 & 0,90533 & \\
\hline & Önlisans & 10 & 2,20 & 0,55777 & \\
\hline & Lisans & 21 & 2,04 & 0,66001 & \\
\hline & Toplam & 107 & 2,11 & 0,87275 & \\
\hline Siyasi & Okuma yazma bilmeyen & 14 & 2,00 & 0,63549 & 0,304 \\
\hline
\end{tabular}


IŞIK, Murşit ve DEMİROK, Kübra - Sosyal Politika Kapsamında Kamu Kuruluşları Tarafindan Bir Dezavantajlı Grup Olarak Engellilere Yönelik Verilen Hizmetlerin Etkinliği: Isparta İli Örneği

\begin{tabular}{|c|c|c|c|c|}
\hline \multirow{4}{*}{ Haklar } & İlköğretim & 20 & 1,98 & 0,76294 \\
\cline { 2 - 5 } & Ortaöğretim & 14 & 1,98 & 0,78117 \\
\cline { 2 - 5 } & Lise & 28 & 2,39 & 0,95846 \\
\cline { 2 - 5 } & Önlisans & 10 & 1,82 & 0,60150 \\
\cline { 2 - 5 } & Lisans & 21 & 2,13 & 0,63549 \\
\cline { 2 - 5 } & Toplam & 107 & 2,10 & 0,78841 \\
\hline
\end{tabular}

$* \mathrm{P}<0,05$

İstihdam alt boyutunda okuma yazma bilmeyen katılımcılar ortalama 1,14 ile "kesinlikle katılmıyorum" cevab1 verirken, diğer katılımcılar "katılmıorum" cevabıyla farklılaşmaktadır. Buna göre katılımcılar işsiz olduklarını ve iş aradıklarını, iş ararken sorunlar yaşadıklarını, il sınırları içerisinde engeline uygun istihdam olanaklarına ulaşabildiklerini, istihdam konusunda yapılan çalışmaları yeterli bulduklarını ve çalışma ortamlarının kendilerine uygun olduklarını düşünmemektedirler. Katılımcıların aynı türde cevapların olması, genel dağılımla ilgilidir.

Tablo 20. Engel Türü Değişkenine Göre Farklılık Analizi

\begin{tabular}{|c|c|c|c|c|c|}
\hline Boyutlar & Grup & Sayı (N) & Ortalama & St.Sapma & $\mathbf{p}$ \\
\hline \multirow{8}{*}{ Sağlık } & İşitme & 3 & 2,13 & 0,61101 & \multirow{8}{*}{0,557} \\
\hline & Fiziksel & 41 & 2,48 & 0,79473 & \\
\hline & Görme & 30 & 2,24 & 0,56247 & \\
\hline & Süreğen Hastalık & 10 & 2,44 & 0,94657 & \\
\hline & Zihinsel & 14 & 2,61 & 0,83192 & \\
\hline & Ruhsal ve Duygusal & 1 & 2,00 & - & \\
\hline & Otizm & 8 & 2,67 & 0,58493 & \\
\hline & Toplam & 107 & 2,43 & 0,71646 & \\
\hline \multirow{8}{*}{ Ulaşım } & İşitme & 3 & 2,55 & 0,34694 & \multirow{8}{*}{0,996} \\
\hline & Fiziksel & 41 & 2,84 & 1,00758 & \\
\hline & Görme & 30 & 2,77 & 0,63023 & \\
\hline & Süreğen Hastalık & 10 & 2,85 & 0,91439 & \\
\hline & Zihinsel & 14 & 2,72 & 1,00556 & \\
\hline & Ruhsal ve Duygusal & 1 & 2,50 & - & \\
\hline & Otizm & 8 & 2,85 & 0,58035 & \\
\hline & Toplam & 107 & 2,79 & 0,84605 & \\
\hline \multirow{8}{*}{ Şehircilik } & İşitme & 3 & 2,00 & 0,88192 & \multirow{8}{*}{0,091} \\
\hline & Fiziksel & 41 & 2,52 & 0,78013 & \\
\hline & Görme & 30 & 2,13 & 0,45080 & \\
\hline & Süreğen Hastalık & 10 & 2,53 & 0,80814 & \\
\hline & Zihinsel & 14 & 2,20 & 0,76566 & \\
\hline & Ruhsal ve Duygusal & 1 & 3,00 & - & \\
\hline & Otizm & 8 & 1,93 & 0,34431 & \\
\hline & Toplam & 107 & & 0,69595 & \\
\hline \multirow{8}{*}{ Güvenlik } & İşitme & 3 & 2,31 & 0,57735 & \multirow{8}{*}{0,136} \\
\hline & Fiziksel & 41 & 3,33 & 0,93166 & \\
\hline & Görme & 30 & 3,15 & 0,61214 & \\
\hline & Süreğen Hastalık & 10 & 3,73 & 0,53748 & \\
\hline & Zihinsel & 14 & 3,30 & 1,30721 & \\
\hline & Ruhsal ve Duygusal & 1 & 3,14 & - & \\
\hline & Otizm & 8 & 4,00 & 0,58248 & \\
\hline & Toplam & 107 & 3,12 & 0,87307 & \\
\hline \multirow{2}{*}{ Eğitim } & İşitme & 3 & 3,34 & 0,50000 & \multirow{2}{*}{0,014} \\
\hline & Fiziksel & 41 & 2,50 & 0,79413 & \\
\hline
\end{tabular}




\begin{tabular}{|c|c|c|c|c|c|}
\hline & Görme & 30 & 3,22 & 0,66609 & \\
\hline & Süreğen Hastalık & 10 & 2,56 & 0,77100 & \\
\hline & Zihinsel & 14 & 2,80 & 0,91331 & \\
\hline & Ruhsal ve Duygusal & 1 & 3,12 & - & \\
\hline & Otizm & 8 & 3,25 & 0,78774 & \\
\hline & Toplam & 107 & 2,56 & 0,80738 & \\
\hline \multirow{8}{*}{$\begin{array}{c}\text { Sosyal } \\
\text { Aktivite }\end{array}$} & İşitme & 3 & 2,91 & 0,85527 & \multirow{8}{*}{0,963} \\
\hline & Fiziksel & 41 & 2,05 & 0,86938 & \\
\hline & Görme & 30 & 2,47 & 0,86185 & \\
\hline & Süreğen Hastalık & 10 & 2,41 & 0,83537 & \\
\hline & Zihinsel & 14 & 2,38 & 0,56681 & \\
\hline & Ruhsal ve Duygusal & 1 & 2,29 & - & \\
\hline & Otizm & 8 & 2,41 & 0,54917 & \\
\hline & Toplam & 107 & 2,41 & 0,79350 & \\
\hline \multirow{8}{*}{$\begin{array}{l}\text { Toplumsal } \\
\text { İlişki }\end{array}$} & İşitme & 3 & 4,50 & 1,32288 & \multirow{8}{*}{0,129} \\
\hline & Fiziksel & 41 & 4,32 & 1,97044 & \\
\hline & Görme & 30 & 4,08 & 1,66134 & \\
\hline & Süreğen Hastalık & 10 & 3,70 & 1,45678 & \\
\hline & Zihinsel & 14 & 5,00 & 2,19421 & \\
\hline & Ruhsal ve Duygusal & 1 & 5,00 & - & \\
\hline & Otizm & 8 & 5,00 & 1,57973 & \\
\hline & Toplam & 107 & 4,44 & 1,87452 & \\
\hline \multirow{8}{*}{$\begin{array}{c}\text { Kamudan } \\
\text { Beklenti }\end{array}$} & İşitme & 3 & 2,72 & 0,48105 & \multirow{8}{*}{0,151} \\
\hline & Fiziksel & 41 & 2,99 & 0,69573 & \\
\hline & Görme & 30 & 2,55 & 0,58301 & \\
\hline & Süreğen Hastalık & 10 & 3,00 & 0,56692 & \\
\hline & Zihinsel & 14 & 2,90 & 0,77386 & \\
\hline & Ruhsal ve Duygusal & 1 & 3,36 & - & \\
\hline & Otizm & 8 & 2,84 & 0,43936 & \\
\hline & Toplam & 107 & 2,84 & 0,65698 & \\
\hline \multirow{8}{*}{ İstihdam } & İşitme & 3 & 2,26 & 0,75719 & \multirow{8}{*}{$0,006^{*}$} \\
\hline & Fiziksel & 41 & 2,16 & 0,91750 & \\
\hline & Görme & 30 & 2,27 & 0,79738 & \\
\hline & Süreğen Hastalık & 10 & 2,54 & 0,63979 & \\
\hline & Zihinsel & 14 & 1,71 & 0,82542 & \\
\hline & Ruhsal ve Duygusal & 1 & 3,20 & - & \\
\hline & Otizm & 8 & 1,17 & 0,49497 & \\
\hline & Toplam & 107 & 2,11 & 0,87275 & \\
\hline \multirow{8}{*}{$\begin{array}{l}\text { Siyasi } \\
\text { Haklar }\end{array}$} & İşitme & 3 & 1,58 & 0,38188 & \multirow{8}{*}{0,269} \\
\hline & Fiziksel & 41 & 2,34 & 0,83081 & \\
\hline & Görme & 30 & 1,94 & 0,75339 & \\
\hline & Süreğen Hastalık & 10 & 2,15 & 0,89907 & \\
\hline & Zihinsel & 14 & 1,89 & 0,69139 & \\
\hline & Ruhsal ve Duygusal & 1 & 2,00 & - & \\
\hline & Otizm & 8 & 2,03 & 0,68709 & \\
\hline & Toplam & 107 & 2,10 & 0,78841 & \\
\hline
\end{tabular}

$* \mathrm{P}<0,05$

İstihdam alt boyutunda ruhsal ve duygusal engel türünde olan katılımc1lar ortalama 3,20 ile "kararsızım" cevab1 verirken, diğer katılımcılar "katılmıyorum" ve "kesinlikle katılmıyorum" cevabı ile farklılaşmaktadır. Buna göre ruhsal ve duygusal engel türündeki bireyler işsiz ve iş aradıklarına, iş ararken sorunlar yaşadıklarına, il sınırları 
IŞIK, Murşit ve DEMIROK, Kübra - Sosyal Politika Kapsamında Kamu Kuruluşları Tarafindan Bir Dezavantajlı Grup Olarak Engellilere Yönelik Verilen Hizmetlerin Etkinliği: Isparta İli Örneği

içerisinde engellerine uygun istihdam olanaklarına ulaşabildiklerine, istihdam konusunda yapılan çalışmaları yeterli gördüklerine ve çalışma ortamlarının kendileri için uygun olduklarına dair net bir görüş belirtmemektedirler.

Tablo 21. Engel Oranı Değişkenine Göre Farklılık Analizi

\begin{tabular}{|c|c|c|c|c|c|}
\hline Boyutlar & Grup & Sayı (N) & Ortalama & St.Sapma & $\mathbf{p}$ \\
\hline \multirow{5}{*}{ Sağlık } & $\% 81-\% 100$ & 39 & 2,42 & 0,63773 & \multirow{5}{*}{0,204} \\
\hline & $\% 61-\% 80$ & 24 & 2,60 & 0,77796 & \\
\hline & $\% 40-\% 60$ & 40 & 2,29 & 0,71747 & \\
\hline & $\% 39-\% 20$ & 4 & 2,90 & 0,93095 & \\
\hline & Toplam & 107 & 2,43 & 0,71646 & \\
\hline \multirow{5}{*}{ Ulaşım } & $\% 81-\% 100$ & 39 & 2,68 & 0,67840 & \multirow{5}{*}{0,321} \\
\hline & $\% 61-\% 80$ & 24 & 2,95 & 0,81687 & \\
\hline & $\% 40-\% 60$ & 40 & 2,75 & 0,98634 & \\
\hline & $\% 39-\% 20$ & 4 & 3,37 & 0,92671 & \\
\hline & Toplam & 107 & 2,79 & 0,84605 & \\
\hline \multirow{5}{*}{ Şehircilik } & $\% 81-\% 100$ & 39 & 2,16 & 0,58426 & \multirow{5}{*}{0,100} \\
\hline & $\% 61-\% 80$ & 24 & 2,20 & 0,61040 & \\
\hline & $\% 40-\% 60$ & 40 & 2,52 & 0,81753 & \\
\hline & $\% 39-\% 20$ & 4 & 2,50 & 0,49065 & \\
\hline & Toplam & 107 & 2,31 & 0,69595 & \\
\hline \multirow{5}{*}{ Güvenlik } & $\% 81-\% 100$ & 39 & 3,55 & 0,87204 & \multirow{5}{*}{0,310} \\
\hline & $\% 61-\% 80$ & 24 & 3,25 & 0,62554 & \\
\hline & $\% 40-\% 60$ & 40 & 3,20 & 0,89729 & \\
\hline & $\% 39-\% 20$ & 4 & 3,25 & 1,70783 & \\
\hline & Toplam & 107 & 3,34 & 0,87307 & \\
\hline \multirow{5}{*}{ Eğitim } & $\% 81-\% 100$ & 39 & 2,71 & 0,70752 & \multirow{5}{*}{0,132} \\
\hline & $\% 61-\% 80$ & 24 & 3,00 & 0,80420 & \\
\hline & $\% 40-\% 60$ & 40 & 3,00 & 0,88070 & \\
\hline & $\% 39-\% 20$ & 4 & 3,56 & 0,65749 & \\
\hline & Toplam & 107 & 2,91 & 0,80738 & \\
\hline \multirow{5}{*}{$\begin{array}{c}\text { Sosyal } \\
\text { Aktivite }\end{array}$} & $\% 81-\% 100$ & 39 & 2,35 & 0,85770 & \multirow{5}{*}{0,932} \\
\hline & $\% 61-\% 80$ & 24 & 2,48 & 0,57508 & \\
\hline & $\% 40-\% 60$ & 40 & 2,43 & 0,84967 & \\
\hline & $\% 39-\% 20$ & 4 & 2,37 & 0,95622 & \\
\hline & Toplam & 107 & 2,41 & 0,79350 & \\
\hline \multirow{5}{*}{$\begin{array}{l}\text { Toplumsal } \\
\text { İlişki }\end{array}$} & $\% 81-\% 100$ & 39 & 4,20 & 1,79443 & \multirow{5}{*}{0,065} \\
\hline & $\% 61-\% 80$ & 24 & 5,00 & 1,83958 & \\
\hline & $\% 40-\% 60$ & 40 & 4,15 & 1,89872 & \\
\hline & $\% 39-\% 20$ & 4 & 5,00 & 1,47196 & \\
\hline & Toplam & 107 & 4,44 & 1,87452 & \\
\hline \multirow{5}{*}{$\begin{array}{l}\text { Kamudan } \\
\text { Beklenti }\end{array}$} & $\% 81-\% 100$ & 39 & 2,71 & 0,62873 & \multirow{5}{*}{0,207} \\
\hline & $\% 61-\% 80$ & 24 & 2,80 & 0,64821 & \\
\hline & $\% 40-\% 60$ & 40 & 2,94 & 0,66544 & \\
\hline & $\% 39-\% 20$ & 4 & 3,31 & 0,78027 & \\
\hline & Toplam & 107 & 2,84 & 0,65698 & \\
\hline \multirow{4}{*}{ İstihdam } & $\% 81-\% 100$ & 39 & 2,15 & 0,83030 & \multirow{4}{*}{0,111} \\
\hline & $\% 61-\% 80$ & 24 & 1,85 & 0,93297 & \\
\hline & $\% 40-\% 60$ & 40 & 2,14 & 0,86077 & \\
\hline & $\% 39-\% 20$ & 4 & 2,95 & 0,59722 & \\
\hline
\end{tabular}




\begin{tabular}{|c|c|c|c|c|c|}
\hline & Toplam & 107 & 2,11 & 0,87275 & \\
\hline \multirow{4}{*}{ Siyasi Haklar } & $\% 81-\% 100$ & 39 & 2,17 & 0,72536 & \\
\cline { 2 - 5 } & $\% 61-\% 80$ & 24 & 2,27 & 0,79713 & \multirow{3}{*}{0,130} \\
\cline { 2 - 5 } & $\% 40-\% 60$ & 40 & 1,89 & 0,82603 & \\
\cline { 2 - 5 } & $\% 39-\% 20$ & 4 & 2,56 & 0,62500 & \\
\cline { 2 - 5 } & Toplam & 107 & 2,10 & 0,78841 & \\
\hline
\end{tabular}

Engel oranı faktörüne göre anketin alt boyutlarına yapılan farklılık analizi sonucunda tüm boyutlarda $\mathrm{p}>0,05$ olduğundan anlamlı bir farklılık gözlemlenmemiştir.

\section{SONUÇ}

Genel olarak insan iradesi dışında gerçekleşen engellilik, birey açısından bir yandan bir sağlık sorunu olmakla birlikte, diğer yandan da bireyi toplumsal yaşamdan soyutlayan, hareket kabiliyetini sınırlandıran dezavantajlı bir durumdur. Engellilik, ilk başta sadece tıbbi bir sorun gibi görülse de zamanla bu sorunun kişinin iş, sosyal ve özel hayatını tamamen etkilediği göz ardı edilmemelidir. Bu nedenle engelliliğin sosyolojik ve psikolojik olumsuz etkileri de optimal bir şekilde tespit edilerek, çözüme kavuşturulmalıdır. Bu kapsamda önleyici ve giderici tedbirler almak, alternatif çözüm önerileri sunmak, sorunun tespit ve çözümünde engelli bireylerin paydaş olarak katılımını sağlamak önemli adımlardır. Bu adımların engellilere yönelik bütüncül kamu politikaları ve bu politikaların hayata geçmesini sağlayacak hukuk normları ile bir bütünlük arz edecek şekilde hayata geçirilmesi gerekmektedir. Bu bütünsellik engelliler ile ilgili sorunların tespit edilmesi ve bu sorunlara çözümler üretilmesi açısından önemlidir.

Engelliler ile ilgili temel sorunlardan birisi istihdamdır. Her ne kadar Devlet Memurları Kanunu ve İş Kanunu başta olmak üzere birçok hukuk normu ile bu konuda olumlu düzenlemeler yapılmış olmakla birlikte bu konuda yeterli düzeyde bir gelişme henüz sağlanamamıştır. Sadece istihdam edilmeleri değil, aynı zamanda istihdamın kapsamı, türü, etkinliği ve verimliliği de önemlidir. Sadece resmi bir istihdamın olması engelliler için önemlidir. Ancak bu bağlamda yeterli değildir. Engelli bireylerin de diğer çalışanlar gibi kariyer yolculuklarının olması, farkındalık oluşturabilecek eğitim, imkân, istihdam, yetki ve desteklere sahip olması gerekmektedir. Ancak reel sektörde genel olarak engelli bireylerin istihdamı ile ilgili işverenlerde isteksizlikler olabilmektedir. Bu durum engelli bireylerin kanuni zorunluluklar nedeniyle basit ve niteliksiz işlerde istihdam edilmelerine neden olmaktadır. Hâlbuki engel durumları da dikkate alındığında birçok engelli bireyin diğer insanlardan geri kalmayacak düzeyde işletmeye katkı sağlayabilecekleri önemli bir ayrıntıdır. Bu bağlamdaki bir istihdam yaklaşımı verimsizlik, isteksizlik, emek kaybı, vs. olumsuz örgütsel davranışların ortaya çıkmasına neden olmaktadir.

Engelli bireylerin sorunları istihdam yani iş hayatı ile sınırlı değildir. Özel ve sosyal yaşamlarında da engelleri nedeniyle dezavantajlı bir duruma düşerek muhtelif sorunlar ile mücadele etmek durumunda kalmaktadırlar. Bu sorunların çözümü noktasında gerek merkezi idare olan devlet ve gerekse yerel idareler olan belediyeler önemli kamusal hizmetler sunmaktadırlar. Bu hizmetlerin tüm engellilere ulaşması, dezavantajlarından dolayı karşılaştıkları engelleri ortadan kaldırmaları, toplum ile daha çok bütünleştirmeleri, firsat eşitliği oluşturmaları ve diğer birçok olumlu etkileri nedeniyle önemli bir faktördür. Bu nedenle de engelliler ile ilgili sorunların tespit edilmesi, hizmetlere tam ve etkin bir erişim sağlanması, hizmetler ile ilgili memnuniyet düzeylerinin ölçülmesi kamu hizmetlerinin sürdürülebilirliği, etkinliği ve devamlılı̆g açısından oldukça önemlidir.

Yapılan çalışmada Isparta İli sınırları içerisinde ikamet eden engelli bireylerin devlet tarafından sunulan kamu hizmetleri ile ilgili memnuniyet düzeylerinin ölçülmesi amaçlanmıştır. Bu kapsamda oluşturulan ankette mevcut olan bağımlı ve bağımsız değişkenler arasında anlamlı farklılıkların olup olmadığının tespiti için T-Testi ve Anova Testleri uygulanarak bulgular elde edilmiştir. Yapılan araştırma neticesinde, çalışma durumu açısından çalışan engelli bireylerin, işsiz ve emekli bireylere göre daha fazla olduğu görülmüştür. Gelir durumu açısından ise geliri olmayan engellilerin, diğer engelli sosyal gruplara göre fazla olduğu tespit edilmiştir.

Araştırmaya katılan engelli bireylerin kamu sektöründe daha büyük oranda istihdam edildiği; yine ağırlıklı çoğunluğunun bir sosyal güvenceye sahip olduğu görülmüştür. Engel türü açısından katılımcıların ençok fiziksel engele sahip olduğu tespit edilmiştir. Engel oranında, "\%81-\%100 arası" engele sahip olan katılımcıların, diğer gruplardan daha fazla olduğu görülmüştür. Farklılık analizinde ise; sadece cinsiyet, medeni durum ve engel oranı ölçeklerinde anlamlı farklılığa rastlanmamıştır. Yapılan araştırma neticesinde tespit edilen sorunlar ve yetersizlikler ile ilgili olarak çözüm olarak ileri sürülebilecek bazı öneriler şunlar olabilir; 
IŞIK, Murşit ve DEMİROK, Kübra - Sosyal Politika Kapsamında Kamu Kuruluşları Tarafından Bir Dezavantajlı Grup Olarak Engellilere Yönelik Verilen Hizmetlerin Etkinliği: Isparta İli Örneği

- Tiyatro ve sinema gibi kültürel faaliyetlerde engelli bireyler için seslendirme imkanı sağlanabilir.

- Otobüs duraklarında engelliler için seslendirme, kabartma, görsel bilgilendirme aparatları, vb. teknolojik araçlar yerleştirilebilir.

- Ulaşımda görev yapan personelin başta engelliler ile iletişim olmak üzere mesleki eğitimden geçirilmeleri ve bu konuda periyodik olarak denetlenmeleri gerekmektedir.

- Tekerlekli sandalye kullanan engelli bireylerin duraktan otobüse binmeleri ve yine aynı şekilde otobüsten durağa inmeleri ile ilgili fiziksel düzenlemeler yapılması, bu konuda ayrı alanlar açılması, elektrikli indirme-kaldırma sistemlerinin oluşturulması gerekmektedir.

- Görme engelliler için kabarmalı yürüyüş alanlarının daha çok yaygınlaştırılması ve bu yollar üzerindeki olası engellerin kaldırılması ve ortaya çıkmasının engellenmesi gerekmektedir.

- Engelliler kent içi yaşamını kolaylaştıracak android yazılımlar geliştirilmelidir.

\section{KAYNAKÇA}

ALTAN, Ömer Zühtü (2007), Sosyal Politika, Anadolu Üniversitesi AÖF Yayını, Eskişehir.

BAYDOĞAN, Handan (2012), "Dezavantajlı Gruplara Yönelik Aktif İstihdam Politikalarının Etkinliği", Yüksek Lisans Tezi, Cumhuriyet Üniversitesi Sosyal Bilimler Enstitüsü, Sivas.

BURCU, Esra (2015), Engellilik Sosyolojisi, Anı Yayınc1lık, Ankara.

GENÇ, Yusuf ve ÇAT, Güldane (2013), "Engellilerin İstihdamı ve Sosyal İçerme İlişkisi", Akademik İncelemeler Dergisi, S.8(1), ss.363-393.

GÖNÜLAÇAN, Ayşenur (2016), “Türkiye'de Engelli İstihdamı ve İşverenlerin Engelli İstihdamına Yönelik Tutumları: Trabzon Örneği", Yüksek Lisans Tezi, Süleyman Demirel Üniversitesi Sosyal Bilimler Enstitüsü, Isparta.

HACIBEBEKOĞLU Adnan, OĞUZ YİĞİTBAŞI, Gülşah, HACIBEBEKOĞLU, Meliha, KAYNAR, Tuğçe ve MURATDAĞI, Sedef (2015), "Nazilli'de Engellilerin Memnuniyet Analizi”, Araştırma Raporu, GEKA - Güney Ege Kalkınma Ajansı Yayını, Denizli, https://geka.gov.tr/uploads/pages_v/nazillide-engellilerinmemnuniyet-analizi-2015.pdf (Erişim Tarihi: 18.04.2019).

İZCI, Ferit, ATMACA, Yıldız ve YILMAZ, Vedat (2019), "Kamu Kurumlarında İtibar Yönetimi: Kurumsal İtibarı Ölçme ve Değerlendirme", ASEAD Avrasya Sosyal ve Ekonomi Araştırmaları Dergisi, S.7(6), ss.302-316.

MECEK, Mehmet ve GÜNEY, Mehmet Sait (2017), “Türkiye'de Engelli Personel İstihdamının Çalışanlar Açısından Değerlendirilmesi”, Belediyelerin Geleceği ve Yeni Yaklaşımlar (Ed. Mahmut Güler, A.Menaf Turan), Marmara Belediyeler Birliği Kültür Yayınları, İstanbul, C.1, ss.379-393.

OKUR, Nejla ve ERDUGAN, Fatma Erbil (2010), "Sosyal Haklar ve Özürlüler: Özürlülük Modelleri Bağlamında Tarihsel Bir Değerlendirme”, 2. Sosyal Haklar Sempozyumu Bildiriler Kitabı, Pamukkale Üniversitesi Yayını, 4-6 Kasım 2010 - Denizli, ss.245-263, https://silo.tips/download/sosyal-haklar-vezrller-zrllk-modeller-balaminda-tarhsel-br-deerlendrme (Erişim Tarihi: 17.04.2019).

ORHAN, Serdar (2013), Türkiye'de Özürlü Dostu İstihdam Politikaları (Durum Analizi ve Öneriler), T. C. Çalışma ve Sosyal Güvenlik Bakanlığı Çalışma ve Sosyal Güvenlik Eğitim ve Araştırma Merkezi Yayınları, Ankara.

ÖLMEZOĞLU, Necla İrem (2015), “Çalışma Yaşamında Engelliler: Gümüşhane İli Engelli İstihdamına İlişsin Emek Arz Yönlü Bir Araştırma", Yüksek Lisans Tezi, Gazi Üniversitesi Sosyal Bilimler Enstitüsü, Ankara.

ÖZ, Cihan Selek ve ORHAN, Serdar (2012), “Özürlü İstihdam Yöntemlerinin Uygulanabilirliği Üzerine Bir Değerlendirme”, Çalışma İlişkileri Dergisi, S.3(2), ss.36-48.

ÖZMETE, Emine (2012), “Haklar Temelinde Engellilik Modelleri ve Sosyal Hizmet”, Engelsiz Toplumu İnşa Etme ve Sosyal Hizmet Paneli, Atatürk Üniversitesi AÖF Yayınları (E-Sunum), Erzurum. 
SEVGİ ENGELlíler DERnEĞİ (2015), Muş’ta Engelli Memnuniyet Düzeyinin Araştırılması Projesi, DAKA - Doğu Anadolu Kalkınma Ajansı Yayını, Muş.

SEYYAR, Ali (2006), Özürlülere Adanmış Sosyal Politika Yazları, Adapazarı Büyükşehir Belediyesi Yayınları, Adapazarı (Sakarya).

ŞAHAN, Emre Can (2018), “Çalışma Hayatına Katılımda Engellilerin Yaşamış Oldukları Sorunlar: Tekirdă̆ Süleymanpaşa Örneği”, Yüksek Lisans Tezi, Tekirdağ Namıl Kemal Üniversitesi Sosyal Bilimler Enstitüsü, Tekirdağ.

T.C. BAŞBAKANLIK ÖZÜRLÜLER İDARESİ BAŞKANLIĞI (1999), I. Özürlüler Şurası Kitabı, Takav Yayınc1lik, Ankara.

TAŞKESEN, Mustafa Özcan ve GÖNÜLLÜ TAŞKESEN, Canan (2015), Engellilik ve Sosyal Hizmet, Karaağaç Yayıncılık, Ankara.

TOKOL, Aysen (1997), Sosyal Politika, Uludağ Üniversitesi Güçlendirme Vakfi Yayını, Bursa.

TUNA, Orhan ve YALÇINTAŞ, Nevzat (2011), Sosyal Siyaset, Filiz Kitabevi, İstanbul.

ÜNAL, Vehbi (2018), “Engellilerin Engelliliğe Bakışı ve Dine Yaklaşımları”, Cumhuriyet İlahiyat Dergisi, S.22(3), ss.1457-1482.

Türkiye Cumhuriyeti Anayasası (09.11.1982 tarih ve 17863 (Mükerrer) sayılı Resmi Gazete).

657 sayılı Devlet Memurları Kanunu (23.07.1965 tarih ve 12056 sayılı Resmi Gazete).

4857 sayılı İş Kanunu (10.06.2003 tarih ve 25134 sayılı Resmi Gazete).

5378 sayılı Engelliler Hakkında Kanun (07.07.2005 tarih ve 25868 sayılı Resmi Gazete).

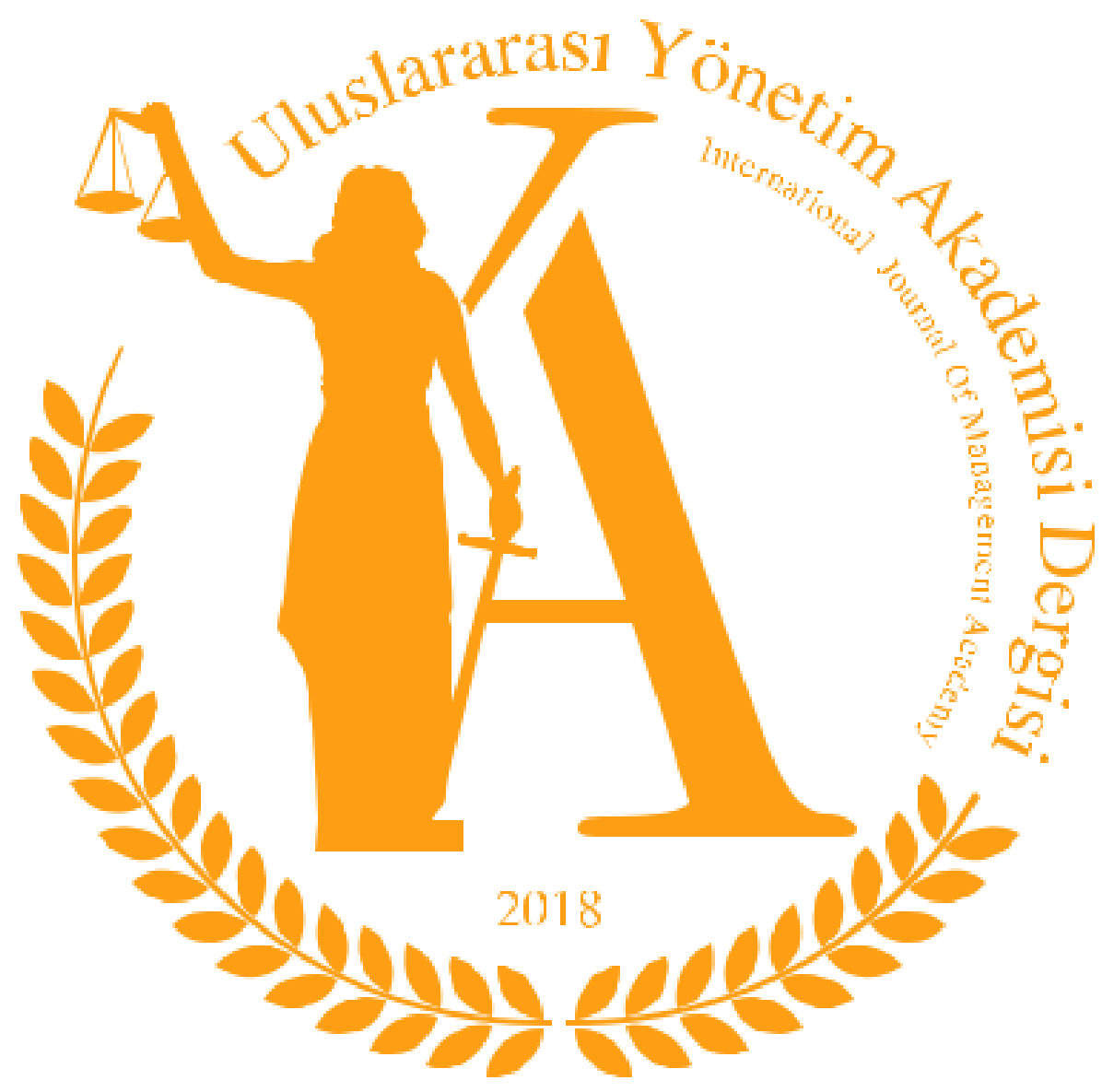

